\title{
Communications of the Association for Information Systems
}

Volume 21

Article 2

9-24-2007

\section{The Information Systems Academic Discipline in Australia}

Guy G. Gable

Queensland University of Technology, Australia, g.gable@qut.edu.au

Follow this and additional works at: https://aisel.aisnet.org/cais

\section{Recommended Citation}

Gable, Guy G. (2007) "The Information Systems Academic Discipline in Australia," Communications of the Association for Information Systems: Vol. 21 , Article 2.

DOI: $10.17705 / 1$ CAIS.02102

Available at: https://aisel.aisnet.org/cais/vol21/iss1/2 


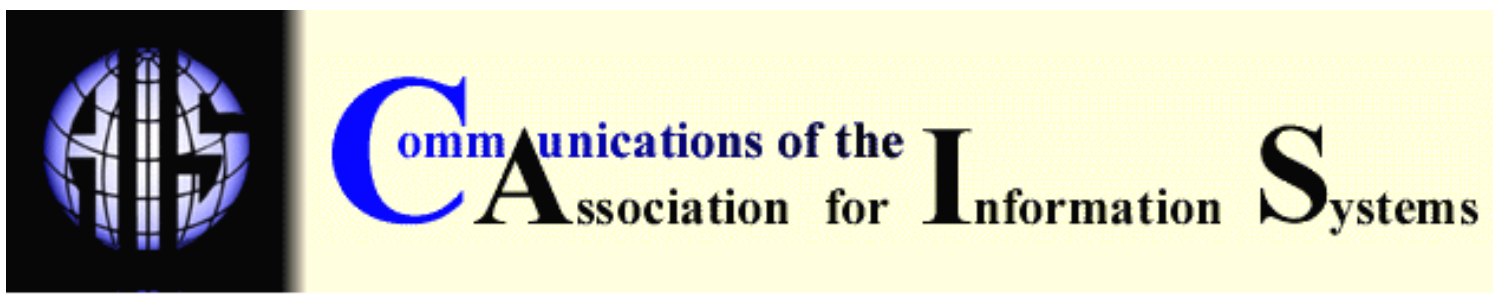

\title{
THE INFORMATION SYSTEMS ACADEMIC DISCIPLINE IN AUSTRALIA
}

Guy G. Gable

School of Information Systems

Queensland University of Technology, Australia

g.gable@qut.edu.au

\begin{abstract}
This paper reports a descriptive case study of the IS academic discipline in Australia. One in a series of nine papers comprising a special issue of Communications of the AIS (CAIS) titled "The Information Systems Academic Discipline in Pacific Asia," this sub-study sought to establish the "beginnings" of a cumulative and ongoing effort to track and report on, and reflect upon the evolution and state of the IS academic discipline in Australia (and Pacific Asia and ultimately other world regions). This paper clarifies the role of the Australian study as a preliminary to the larger Pacific Asia study, and draws upon a series of case studies of Australian states and territories to present the Australian situation. The case study protocol, based in Ridley's [2006] framework on the evolution of disciplines, suggests an inverse relationship between the impact of local contingencies and a discipline's degree of professionalism and maturity. Analysis of Australian data reveals considerable diversity in IS research and teaching across the nation, reflecting the wide geographic spread of universities in Australia. Although in general IS research is not highly contingent upon local exigencies and environmental pressures, the topics researched often reflected personal interests and are only weakly coordinated across research sites. At this time IS in Australia does not possess a unique symbol system that allows unambiguous communication between initiates within the field.
\end{abstract}

Keywords: Information Systems, IS discipline, Australian universities, case study

\section{INTRODUCTION}

This paper is one of a series of nine papers comprising a special issue of Communications of the AIS (CAIS) titled "The Information Systems Academic Discipline in Pacific Asia." This paper reports a descriptive case study of the IS academic discipline in Australia. The text box following provides an introduction to the parent, IS in Pacific Asia study, whose aims, questions, theory base, overarching design, study team, and quality assurance process are detailed in the paper "The Information Systems Academic Discipline in Pacific Asia: A Contextual Analysis" [Gable 2007a]. 


\section{The State of the Information Systems Academic Discipline in Pacific Asia}

Figure 1 depicts the main components of the study "The State of the Information Systems Academic Discipline in Pacific Asia." The Pacific Asia study is motivated from a recognition that Information Systems as an academic discipline has evolved differentially around the world. The genesis of the study was a panel of the 6th Pacific Asia Conference on Information Systems (PACIS'02), Tokyo, Japan, ultimately resulting in formal project commencement in 2004 with AIS endorsement and seed funding.

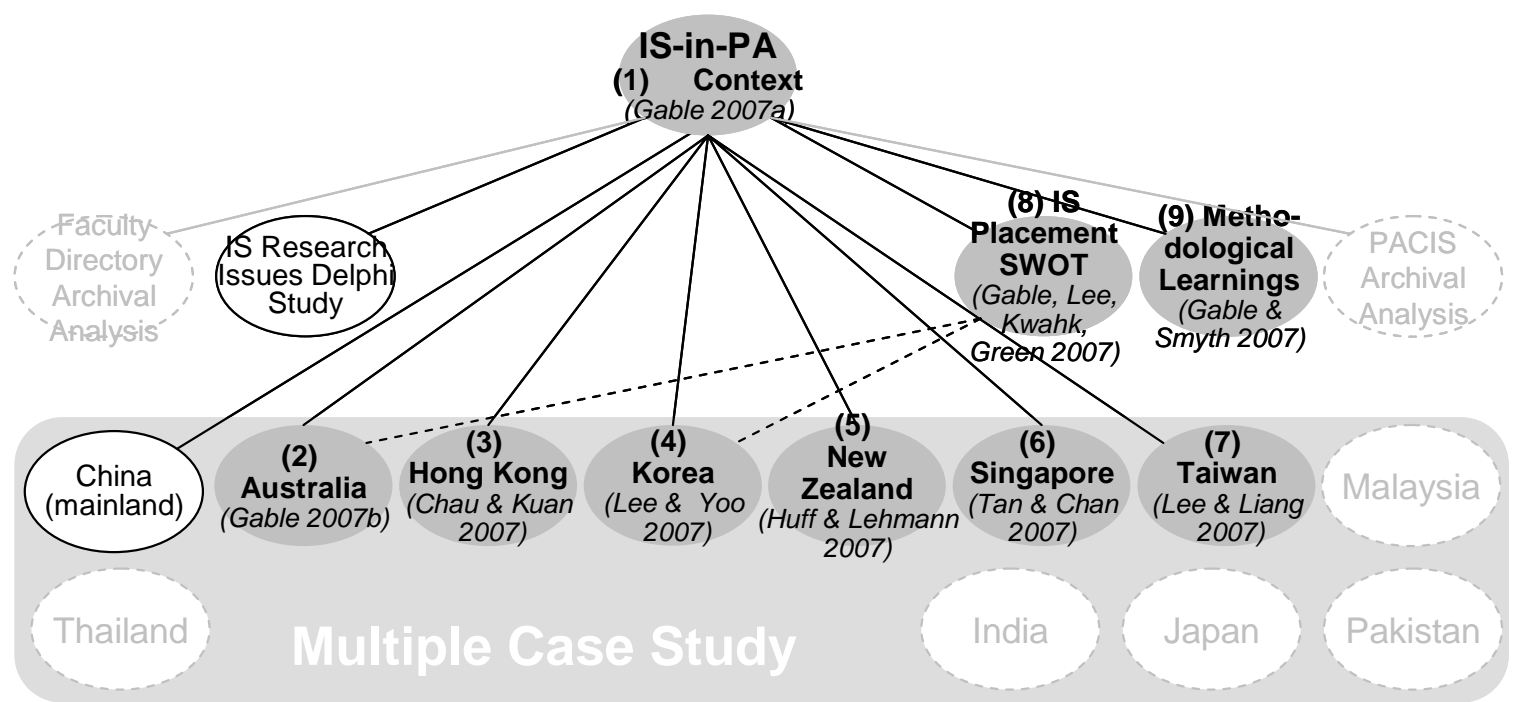

Figure 1. The IS in Pacific Asia Region Sub-Studies

Principal of the several related sub-studies is a series of case studies across the states ${ }^{1}$ of Pacific Asia. The overall study has from the outset been designed and executed with the expectation that it would be extended and repeated over time. It was decided early on to restrict the first iteration of the study to those areas in the region where IS is relatively more visible internationally Australia, Hong Kong (China), Korea, New Zealand, Singapore and Taiwan.

Shaded ovals in Figure 1 represent those components completed in the first execution, with results reported in this special issue of CAIS. Unshaded ovals represent components in progress (i.e. Mainland China case study), and dashed ovals represent components soon to commence.

The largely exploratory and descriptive state case studies employed a common research framework [Ridley 2006]. The framework considers the current and past state of IS in Pacific Asia universities from the perspective of the development of a discipline. The framework was guided by Whitley's Theory of Scientific Change [1984a, 1984b]. It suggests that there is an inverse relationship between the impact of local contingencies and a discipline's degree of professionalism and maturity.

Given the descriptive and exploratory character of the overall study, the team harbored no illusions regarding the ultimate completeness of issues to be identified, related evidence to be gathered, and analyses to be conducted. It was acknowledged that the study offers a mere starting point for ongoing monitoring of the state of IS in the Pacific Asia region. Regardless, efforts were made to achieve some level of representativeness of the evidence and perspectives reported: (1) Selection of the study team - sought region-wide representation. This suggested state-based case reports. Senior and well known IS academics were approached. (2) Interviewees received an early draft of the state report in which their views were recounted. On

\footnotetext{
${ }^{1}$ The term "state" is used to refer to each of the national entities studied. 
the basis of feedback, changes were implemented by the state teams. (3) Selected "within state" local experts were sent a copy of the draft state report for review, aims being to: minimize potential adverse reaction from perceived misrepresentation, try to ensure the report is as representative of the state as possible, enrich the report with further insights, and ensure the process of peer-review results in papers of strong academic standard. (4) All authors on all papers of the special issue reviewed the complete draft special issue.

\section{THE AUSTRALIAN STUDY DESIGN}

In January 2004, a sub-group of the IS in Pacific Asia study team (Gable, Huff, and $\operatorname{Tan}^{2}$ ) met in Auckland and agreed that Australia, having been active in IS academe since the '70s, and having a correspondingly long and internationally visible history of IS research, would provide a useful pilot study in advance of extending the multiple-state case study to other parts of Pacific Asia. This resulted in a proposal to conduct a multiple-case study of the Australian states - the IS in Australia study (Figure 2).

In Figure 2, foreground shaded ovals represent the 12 IS in Australia sub-studies that have been completed and that are summarized in this paper. ${ }^{3}$ These include three background sub-studies (contextual framework, history, and theory framework), and nine evidentiary sub-studies (seven Australian state reports, a research survey, and a "contradictions" piece). ${ }^{4}$ Unshaded ovals represent components that are in progress (e.g. ACIS Archival Analysis) and which will be reported in future. Note that, consistent with the key study aim of "repeatability," "methodological learnings" from the IS in Australia study ${ }^{5}$ are reported, together with all such learnings across the IS in Pacific Asia study, in the final paper of this special issue of CAIS [Gable and Smyth 2007].

Aims of the IS in Australia study are consistent with those of the parent study. The IS in Australia study, like the IS in Pacific Asia study, is descriptive by design, with less emphasis on interpretation, reflecting its "foundational" character." study has from the outset been intended as a service to the IS Academic Profession. The study sought to establish the "beginnings" of a cumulative and ongoing effort to track and report on, and reflect upon the evolution and state of the IS academic discipline in Australia (and Pacific Asia and ultimately other world regions).

Other more specific study aims included:

- to begin documenting characteristics of IS programs across universities in Australia;

- to begin documenting characteristics of IS research across universities in Australia;

- to begin assessing the strength of the IS presence in Australian universities;

- to evaluate the maturity of IS as an academic discipline in Australia;

- to identify emerging trends in IS in Australian universities; and

- to identify main influences on IS in Australian universities.

\footnotetext{
${ }^{2}$ Felix Tan, Auckland University of Technology, who was then the elected AIS Region 3 Council Representative - Sid Huff being co-author of the New Zealand case study (Huff and Lehmann, 2007).

${ }^{3}$ All of which have been individually published in a special issue of the Australasian Journal of Information Systems (AJIS) with the featured theme 'The Information Systems Discipline in Australian Universities'.

${ }_{5}^{4}$ Results of each of these sub-studies are briefly summarized later in this paper.

${ }^{5}$ The 'IS in Australia' study being in several respects a 'pilot', generated a majority of such methodological learnings.

${ }^{6}$ More interpretive discussion is included in [Gable et al. 2007] The Information Systems Academic Discipline in Australia 2006, a book to appear in 2007 that expands upon the AJIS special issue.
} 


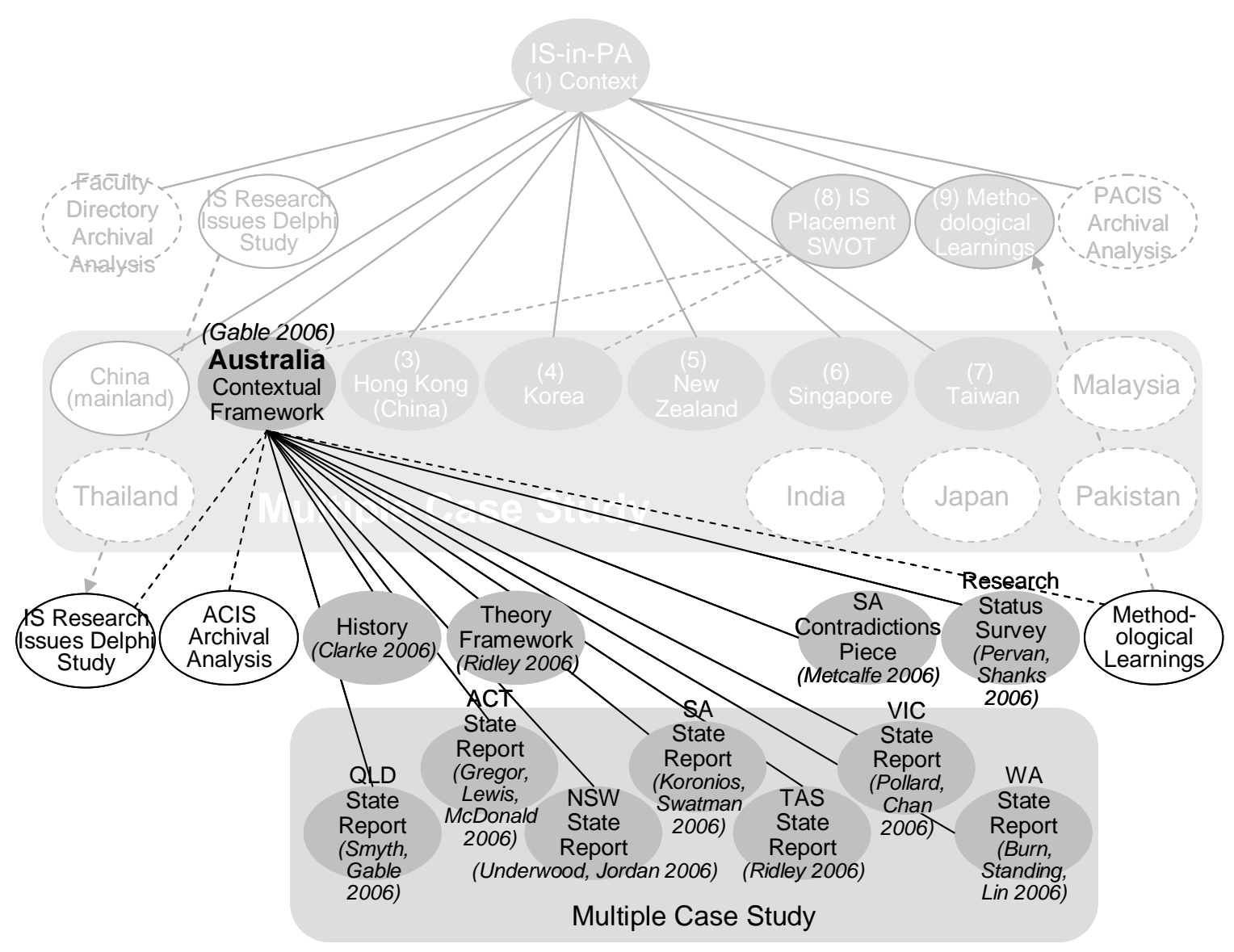

Figure 2. The IS in Australia Study Design

Ridley's theory paper [Ridley 2006a] was used to inform the development of a case study protocol, and some of the foremost IS academics in each state were invited to lead Australian state research teams. Table 1 lists the main IS in Australia study team members.

\section{STUDY APPROACH}

The study approach for the Australian case study is much the same as the one used in all IS in Pacific Asia case studies. It is noted, however, that there was perhaps greater variety in the interpretation and application of the documented study approach across the Australian states and territories than there was across the Pacific Asian states. In example, several of the IS in Australia sub-studies adhered more closely to the relatively more "positivist" Yin [2003] case study method, while others refer more specifically to an "interpretivistic" approach a la Walsham [1995]. Yet others appear to view these approaches as intertwined rather than alternatives.

To guide the direction of the Australian state case studies, a pilot case was conducted in Queensland. A case study protocol was developed and carefully followed. The protocol and writeup of the Queensland pilot case study was then made available to Queensland interviewees and to all team members, across the states, for feedback. The approach adopted in the Queensland pilot was endorsed as appropriate for use in the other Australian states. This protocol was subsequently adopted for use in the Pacific Asia case studies. The final detailed protocol is reported in Gable and Smyth's "Methodological Learnings" paper in this volume of CAIS 
Table 1. The IS in Australia Study Team

\begin{tabular}{rll} 
Home State & Team Member & \\
\hline Queensland & Gable, Guy G & Queensland University of Technology \\
& Smyth, Robert & Queensland University of Technology \\
\hline ACT & Clarke, Roger & Principal Xamax Consultancy Pty Ltd \\
& Gregor, Shirley & Australian National University \\
& Lewis, Ed & Australian Defence Forces Academy, U New South Wales \\
& McDonald, Craig & University of Canberra \\
\hline New South Wales & Jordan, Ernest & Macquarie University \\
& Underwood, Jim & University of Technology -Sydney \\
\hline South Australia & Koronios, Andy & University of South Australia \\
& Metcalfe, Mike & University of South Australia \\
& Swatman, Paula & University of South Australia \\
\hline Tasmania & Ridley, Gail & University of Tasmania \\
\hline Victoria & Chan, Elsie & Australian Catholic University \\
& Pollard, Carol & Appalachian State University \\
& Shanks, Graeme & Monash University \\
\hline West Australia & Burn, Janice & Edith Cowan University \\
& Lin, Chad & Edith Cowan University \\
& Pervan, Graham & Curtin University of Technology \\
& Standing, Craig & Edith Cowan University \\
\hline
\end{tabular}

The next section (II) presents relevant background to the Australian-state case studies. Section III summarizes the Australian-state case study findings. Section IV briefly analyses the administrative location of IS in Australian universities (as detailed in the Australian-state case studies). Section $\vee$ concludes the paper with discussion on study limitations and potential further research.

\section{BACKGROUND}

As a backdrop to the remainder of this paper, this section provides brief discussion on: 1) the eight states and territories of Australia; 2) the university sector in Australia; 3) selected aspects of the history of IS in Australia; 4) a brief description of the Australasian Conference on Information Systems (ACIS), the main IS conference in Australasia; and 5) governance of IS academe in Australia.

\section{AUSTRALIA - EIGHT STATES AND TERRITORIES}

Australia is the world's smallest continent and the sixth-largest country in area. Australia is divided into six states and two main territories. The states are: New South Wales, Queensland, South Australia, Tasmania, Victoria, and Western Australia. The main territories are the Australian Capital Territory and the Northern Territory. Most of Australia's population of more than 20 million is concentrated in the eastern and south-eastern coastal areas with the majority living in the state and territory capital cities. Australia has a western-style capitalist economy with one of the fastest-growing productivity rates in the OECD.

\section{UNIVERSITIES IN AUSTRALIA}

Table 2 lists the 39 universities in Australia, 37 being public, and two private (Bond and Notre Dame). Marginson and Considine [2000] characterised the public universities as "Sandstones," "Redbricks," "Gumtrees," "Unitechs," and "New Universities." The six "Sandstones" were founded in Australia before the first world war. The three "Redbricks" were founded in the 1940s-1950s. 
The ten "Gumtrees" are post-war and pre-Dawkins ${ }^{7}$ general universities founded between the early 1960s and mid -1970s. The five "Unitechs" are former large institutes of technology formed post-Dawkins. The thirteen "New Universities" are other post-Dawkins universities, often formed out of colleges of advanced education; several "New Universities" are specialist regional and/or distance education providers.

Table 2. Australian Universities by State within Era

\begin{tabular}{|c|c|c|c|}
\hline Era / University & State & Unitechs (former Institutes of Technology) & \\
\hline Sandstones (pre WWI) & & 20 University of Technology, Sydney (UTS) & NSW \\
\hline 1 University of Sydney & NSW & 21 Queensland University of Technology (QUT) & QLD \\
\hline 2 University of Queensland (UQ) & QLD & 22 University of South Australia (UniSA) & SA \\
\hline 3 University of Adelaide & SA & 23 RMIT University & VIC \\
\hline 4 University of Tasmania (UTas) & TAS & 24 Curtin University of Technology & WA \\
\hline 5 University of Melbourne & VIC & New Universities (post 1987) & \\
\hline 6 University of Western Australia (UWA) & WA & 25 University of Canberra & ACT \\
\hline Red Bricks (1940-50s) & & 26 Australian Catholic University (ACU) & multi \\
\hline 7 Australian National University (ANU) & ACT & 27 Charles Sturt University (CSU) & NSW \\
\hline 8 University of New South Wales (UNSW) & NSW & 28 Southern Cross University (SCU) & NSW \\
\hline 9 Monash University & VIC & 29 University of Western Sydney (UWS) & NSW \\
\hline Gum Trees (60s to mid-70s) & & 30 Charles Darwin University (CDU) & NT \\
\hline 10 Macquarie University & NSW & 31 Central Queensland University (CQU) & QLD \\
\hline 11 University of New England (UNE) & NSW & 32 University of Southern Queensland (USQ) & QLD \\
\hline 12 University of Newcastle & NSW & 33 University of the Sunshine Coast (USC) & QLD \\
\hline 13 University of Wollongong (UoW) & NSW & 34 University of Ballarat & VIC \\
\hline 14 Griffith University & QLD & 35 Swinburne University of Technology & VIC \\
\hline 15 James Cook University (JCU) & QLD & 36 Victoria University (VU) & VIC \\
\hline 16 Flinders University & SA & 37 Edith Cowan University (ECU) & WA \\
\hline 17 Deakin University & VIC & Private & \\
\hline 18 La Trobe University & VIC & 38 Bond University & QLD \\
\hline 19 Murdoch University & WA & 39 Notre Dame University & WA \\
\hline
\end{tabular}

Note that each of the Australian-state case studies reported in Section III following, lists details of the administrative placement of IS within universities in that Australian state. The administrative placement of IS across the full set of 39 Australian universities is revisited in Section IV.

\section{SELECTED ASPECTS OF THE HISTORY OF IS IN AUSTRALIA}

Clarke [2006] offers a cogent discussion on the evolution of the IS discipline in Australia. He suggests that IS discipline development in Australia emerged in parallel with, and until the end of the 1970s, independently of developments overseas. Clarke refers to three main phases of evolution: the Emergence Phase, the Establishment Phase, and the Consolidation Phase.

During the Emergence Phase (up to 1965) a highly significant federal government initiative was the Programmer in Training (PIT) scheme, the syllabus of which emphasized systems analysis and design, and produced hundreds of ultimately influential senior managers in both the public and the private sector.

Early in the Establishment Phase (1965-1973), departments were created in Colleges of Advanced Education $\left(\mathrm{CAEs}^{8}\right)$ to assist practice with the application of computers in business and government. In parallel, topics about "how to apply the technology" began to emerge in university

7 John Dawkins' white paper, released in 1988, was the beginning of a tide of reforms to the university sector. It not only resulted in the merger of vocationally based colleges with universities but also had significant equity dimensions.

${ }^{8}$ CAEs were established as professionally-oriented tertiary education institutions independent of the universities and regulated by boards in each state. Their brief was much more one of professional community engagement and the teaching of professional skills than of research. They had much in common with the English polytechnics of the time. 
accounting departments, these being relatively more concerned with the "information" than the system. The transfer of PIT to CAEs toward the end of this phase heralded formalized IS education, which then expanded into Institutes of Technology. ${ }^{9}$ Much of this early effort was service teaching, with IS in universities migrating forward from "undergraduate service topics and units $^{10}$ to sub-majors, majors and only later postgraduate teaching and research" [Clarke 2006: $126]$.

At the outset of the Consolidation Phase (1974-1990), the University of New South Wales appointed the first professor of IS, Cyril Brookes, and formed the first university IS department. In 1978 the first Australian was awarded a PhD in IS (Ron Weber at Minnesota under Gordon Davis's supervision) [Clarke 2006]. Ron Weber was the second professor of IS (in 1981), with several further such appointments in the late ' 80 s and about 20 in the 1990s, resulting in over 30 IS professors by 2005 . Early published curricula from the UK and U.S. were too comprehensive and either too computer science or business oriented for the mostly IS service subjects being taught in Australia. Australia's "local" IS curriculum thus sometimes became almost insular. In 1990, for the first time IS was recognised within the Australian Computer Society Accreditation Guidelines. This could be seen as a watershed for IS.

"Through the 1970s and the 1980s the vigour of the discipline in the USA resulted in that country establishing leadership in, and for many years even downright dominance over, the IS discipline" [Clarke 2006: 128]. Philosophies and methods of research were debated through this period, with some acceptance of pluralism. Clarke, in Maynard [1992], depicted IS at that time as occupying "space between the technical and business disciplines, encompassing a range of applied and instrumentalist topics, and interacting closely with many other disciplines and subdisciplines" [Clarke 2006: 128].

Clarke lists seven main clusters of topics or themes in Australian IS since 1965 (with much crossfertilization among the themes): i) technology as an enabler and driver; ii) applications of technology; iii) data management; iv) organizations; v) systems thinking; vi) business school thinking; and vii) information management. The apparent diversity of both curricula and research domains appears perhaps more varied, even, than that of Europe or America.

\section{THE AUSTRALASIAN CONFERENCE ON INFORMATION SYSTEMS}

The Australasian Conference on Information Systems (ACIS) is the main IS conference in the region. Table $3^{11}$ following summarizes key characteristics of ACIS over time. (Though these data have been carefully vetted by several knowledgeable individuals, including all who reviewed this paper, it must be acknowledged, that the data was compiled from multiple and diverse sources across which inconsistencies were observed). ${ }^{12}$

\footnotetext{
${ }^{9}$ Institutes of Technology were specialist CAEs, one in each state capital city, concentrating on the technological professions.

${ }^{10}$ Units - a term used in many Australian universities to refer to a 'subject'.

${ }^{11}$ (AAIS) http://www.aaisnet.org/ maintain the ACIS home page, where a copy of this table has been lodged by the authors.

${ }^{12}$ In example, conference dates were expressed differently in some materials depending on what was being included. e.g. In 1995 the doctoral consortium was held on September 26, and the days on which papers were actually presented were September 27-29. The Proceedings show the dates for the Conference as September 26-29. In other years the doctoral consortium dates may be included in some places and excluded in others. The terms Organising Chair, Conference Chair and Executive Chair seem to be inconsistently used, even for a single conference. There were differences in the counts of papers for some conferences on different pages of the proceedings, and the counts given do not always correspond to the actual number of papers in the proceedings (though they are always very close). Corrections are welcome and should be The Information Systems Academic Discipline in Australia by G.G. Gable
} 
The Australasian Conference on Information Systems will run for its eighteenth consecutive year in December 2007 in Toowoomba. The first conference was held at Monash University in 1990 with the name "First Annual Conference on Information Systems." In 1991 it was called the "Second Annual Conference on Information Systems and Database Special Interest Group." In 1992 it became the "Australian Conference on Information Systems" and in 1994, in recognition of the substantive involvement of New Zealand, the name was changed to the "Australasian Conference on Information Systems" (ACIS). Until the advent of Pacific Asia Conference on Information Systems (PACIS) in 1993, ACIS was the only substantial IS conference in the region. Since 1993, ACIS and PACIS have happily co-existed, attracting a large overlap in delegates.

Attendance has stabilized at around 250 during the past three years; paper submissions around 250 and paper acceptances around 100 (40 percent acceptance). Though a less international conference than PACIS, ACIS tends to attract papers and delegates from around a dozen countries each year (the vast majority of the papers being from Australia and New Zealand).

The first ACIS doctoral consortium on record was in 1995 at Curtin University of Technology. The consortiums began to run regularly from 2001 . In 2005 , the consortium was extended from oneto one-and-a-half days duration. A doctoral thesis prize from the Australian Council of Professors and Heads of Information Systems (ACPHIS) was introduced in 2004 and is now awarded each year at ACIS.

The conference organisation structure has evolved over time. Until the end of 1994 the conference was run by an interim committee. The members of the interim committee were: Roger Clarke (Australian National University), Igor Hawryszkiewycz (University of Technology, Sydney), Ross Jeffery (University of NSW), Ron Weber (University of Queensland), and Peter Weill (University of Melbourne). The decision to finally anoint a rolling ICIS-style ACIS committee and disband the interim committee was made at the end of 1994.

A study of ACIS proceedings over its 16-year history has the potential to reveal a good deal about research in Australian (and New Zealand) universities. To this end, the author of this paper has initiated an archival analysis of ACIS proceedings. All papers from the $16 \mathrm{ACIS}$ conferences have been converted to electronic format, while a full EndNote database has been built to capture salient data from each of the papers.

Though analyses of the ACIS archival material are in progress, ${ }^{13}$ we are able to report some preliminary findings. Counts reported here were done using "Search References" in EndNote. More reliable counts will be available once the data is loaded into the intended database.

All papers have been classified using the classification options:

- Technical

- Behavioural/Managerial

- Educational (i.e. IS curriculum related)

- Other (predominantly research methodology papers)

The papers have also been coded according to topic. This coding is preliminary, and it is our intention that the codes be confirmed by the authors of papers. A 32-topic coding scheme was used based on Barki et al. [2004] and Palvia et al. ]2004]. The choice of the coding scheme was intended to facilitate the comparison of topics covered at ACIS with those covered in IS research topic studies elsewhere.

directed to the Australasian Chapter of the Association for Information Systems http://www.aaisnet.org/.

${ }^{13}$ Special thanks to Karen Stark, Senior Research Associate in the IT Professional Services research program at Queensland University of Technology, who has driven this data capture, coding and preliminary analysis with enthusiasm and whose efforts have gone well beyond the call to produce this important archive.

The Information Systems Academic Discipline in Australia by G.G. Gable 
In the years 1990-1995, about 30 percent of the papers were classified as technical while in the years 2000-2005 only 12 percent were classified this way. In the years 2000-2005, the percentage of papers that were coded as "organizational environment" or "external environment" was approximately double that of the years 1990-1995. These changes support the premise that research in IS has been moving away from a more technical emphasis in the early years and is now placing more importance on the context.

There has been no real pattern to the inclusion of curriculum related topics. Most commonly 7 to 8 percent of papers are curriculum-related. The first five years of the conference include the years of both the highest and lowest percentages of such papers. At the First Annual Conference on Information Systems, three of the fifteen papers (20 percent) were curriculum-related. In 1994 there were no curriculum-related papers.

As new technologies have developed, new topics have emerged, interest in other topics has fallen away and previously discussed topics have taken on a new focus. For example, in recent years research into electronic commerce/inter-organizational systems has peaked, research interest in databases/DBMS has waned somewhat, and there are new stirrings of interest in hardware due mainly to research into mobile devices such as PDAs.

The most popular topics have been:

- IS Development /Methods and Tools: $14 \%$

- Theory of IS: $9 \%$

- Electronic Commerce/Interorganizational Systems: 6\%

- Resource Management/IS Management Issues: 6\%

- IS Education: 5\%

- IS Application Areas: 5\%

Universities who have contributed most papers are:

- Monash University: $8.26 \%$

- University of Melbourne: $5.15 \%$

- Edith Cowan University: $5.07 \%$

- Curtin University of Technology: $4.66 \%$

- Deakin University: $4.5 \%$

- Queensland University of Technology: $4.25 \%$

- University of Wollongong: $4.09 \%$

- University of New South Wales: $4.01 \%$

- University of Tasmania: $3.92 \%$

- Victoria University: $3.76 \%$

While the majority of ACIS papers were from Australasian authors, there has been a significant presence of authors from countries elsewhere in the world. The non-Australasian countries that have contributed the most papers (using first- author country affiliation) are (number of papers in parentheses):

- USA (15)

- UK (13)

- Hong Kong (China) (10)

- Germany (9)

- Norway (9)

- Singapore (7)

- Finland (7)

- South Africa (7) 


\section{GOVERNANCE OF IS ACADEME IN AUSTRALIA}

There exist few formal mechanisms for governing IS across Australia. To the extent that the IS academic community is represented, that representation is through voluntary associations and elected roles, including: Australasian Association for Information Systems (AAIS), Association for Information Systems (AIS), Australian Council of Professors and Heads of Information Systems (ACPHIS), Australian Computer Society (ACS) - Information Systems Board, and representation at the Australian Research Council (ARC).

AAIS, as the local chapter of AIS, established in 2001, is a significant body for representing the interest of IS academics through its links to AIS and other national and international IS groups. AIS, the Association for Information Systems, is the pre-eminent international body for IS academics worldwide. It sees itself as the "professional organization whose purpose is to serve as the premier global organization for academicians specializing in Information Systems." The AIS executive council includes two representatives from each of the three AIS world regions: (1) The Americas; (2) Europe, Middle East and Africa; and (3) Pacific Asia.

The Australian Council of Professors and Heads of Information Systems (ACPHIS) was initiated in 1995 and formalized in 1997. In similar vein to the objectives of AAIS, ACPHIS sees itself as

"the peak body established to represent Australian information systems academics in matters of national and international importance." At a more operational level, ACPHIS provides a forum for discussion on matters relating to the development of information systems as a discipline in Australian universities, and acts to promote collaboration between information systems departments.

The Australian Computer Society (ACS) includes an Information Systems Board. The purpose of the Information Systems Board of ACS is to give a voice on this long-established and influential society specifically to Information Systems practitioners and academics.

Prior to 2001, IS academics in Australia were disadvantaged in seeking research grants from the Australian Research Council; until that year applications for grants to undertake IS research were assessed by academics from fields other than IS. Graham Pervan (as President ACPHIS) and Janice Burn, with the support of other prominent IS academics in Australia, have managed since 2001 to successfully promote appointment of a well qualified and senior IS academic to the ARC College of Experts - Janice Burn (2001-2003), Graeme Shanks (2004-2005) and Michael Rosemann (2006-2007).

\section{THE SEVEN STATE/TERRITORY CASE STUDIES}

The seven Australian state and territory case studies are summarized here. These case studies were reported in detail in 2006 in the Australasian Journal of Information Systems Volume 14, No 1. The emphasis, depth and tone of the seven state reports varies substantially; several being more descriptive or historical; others more of a critical review. Though a common protocol was developed and promulgated, it evolved throughout the study along with the theory base, and its use was not enforced - diversity was encouraged.

Particular emphasis was paid in the study to the administrative placement of IS within university structures. The placement of the IS group in universities can reveal much about the mechanisms of control available to IS academics, yet university structures are constantly changing. In order to gain a more accurate sense of where Information Systems academic groups are currently located 
Table 3a. Australasian Conference on Information Systems: 1990-1998

\begin{tabular}{|c|c|c|c|c|c|c|c|c|c|}
\hline Year & 1990 & 1991 & 1992 & 1993 & 1994 & 1995 & 1996 & 1997 & 1998 \\
\hline City & Melbourne & Sydney & Wollongong & Brisbane & Melbourne & Perth & Hobart & Adelaide & Sydney \\
\hline $\begin{array}{r}\text { Sponsoring } \\
\text { University }\end{array}$ & Monash U & U NSW & $\begin{array}{c}\text { U } \\
\text { Wollongong }\end{array}$ & $\begin{array}{c}\mathrm{U} \\
\text { Queensland }\end{array}$ & Monash U & Curtin U Tech & $\begin{array}{c}\mathrm{U} \\
\text { Tasmania }\end{array}$ & $\begin{array}{l}\text { U South } \\
\text { Australia }\end{array}$ & $\begin{array}{c}\mathrm{U} \text { of New } \\
\text { South Wales }\end{array}$ \\
\hline $\begin{array}{r}\text { program } \\
\text { chair(s) }\end{array}$ & & & & & $\begin{array}{l}\text { Graham } \\
\text { Shanks }\end{array}$ & Mike Newby & $\begin{array}{l}\text { Cathy } \\
\text { Urquhart }\end{array}$ & $\begin{array}{l}\text { David } \\
\text { Sutton }\end{array}$ & $\begin{array}{c}\mathrm{R} \\
\text { Edmundson } \\
\mathrm{D} \text { Wilson }\end{array}$ \\
\hline $\begin{array}{r}\text { conference } \\
\text { chair(s) }\end{array}$ & $\begin{array}{c}\text { I } \\
\text { Hawryszkie } \\
\text { wycz }\end{array}$ & & $\begin{array}{c}\text { Rob } \\
\text { MacGregor }\end{array}$ & & David Arnott & $\begin{array}{l}\text { Graham } \\
\text { Pervan }\end{array}$ & $\begin{array}{l}\text { Chris } \\
\text { Keen }\end{array}$ & $\begin{array}{c}\text { Terry } \\
\text { Robbins- } \\
\text { Jones }\end{array}$ & Ross Jeffery \\
\hline $\begin{array}{r}\text { organising } \\
\text { chair(s) }\end{array}$ & $\begin{array}{c}\text { R Jeffery } \\
\text { K Dampney }\end{array}$ & & & $\begin{array}{c}\text { Paul } \\
\text { Ledington }\end{array}$ & David Arnott & $\begin{array}{l}\text { Graham } \\
\text { Pervan }\end{array}$ & & & \\
\hline dates & 6 Feb & 4-5 Feb & $5-8 \mathrm{Oct}$ & 28-30 Sep & 27-29 Sep & 27-29 Sep & 11-13 Dec & $\begin{array}{c}29 \text { Sep-2 } \\
\text { Oct }\end{array}$ & $\begin{array}{c}29 \text { Sep - } 2 \\
\text { Oct }\end{array}$ \\
\hline duration & 1 day & 2 days & & 3 days & 3 days & 3 days & 3 days & & \\
\hline $\begin{array}{r}\text { \# } \\
\text { submissions }\end{array}$ & & & 79 & $80+$ & 85 & 82 & 112 & & 98 \\
\hline $\begin{array}{c}\text { \# countries } \\
\text { (1st author) }\end{array}$ & 1 & 2 & 8 & 6 & 6 & 8 & 6 & 9 & 3 \\
\hline $\begin{array}{r}\text { acceptance } \\
\text { rate }\end{array}$ & & & $57 \%$ & $<75 \%$ & $66 \%$ & $77 \%$ & $50 \%$ & & $61 \%$ \\
\hline $\begin{array}{r}\text { parallel } \\
\text { streams }\end{array}$ & 1 & & & 3 & & 3 & & & \\
\hline $\begin{array}{r}\text { papers in } \\
\text { proceedings }\end{array}$ & 15 & 29 & 45 & 60 & 56 & 63 & 56 & 62 & 60 \\
\hline panels & $\begin{array}{c}\text { None } \\
\text { proceedings }\end{array}$ & $\begin{array}{c}\text { None in } \\
\text { proceedings }\end{array}$ & 9 & & 3 & 5 & 2 & & \\
\hline \multicolumn{10}{|l|}{ tutorials } \\
\hline $\begin{array}{r}\text { keynote } \\
\text { speakers }\end{array}$ & $\begin{array}{l}\text { None } \\
\text { indicated in } \\
\text { proceedings }\end{array}$ & $\begin{array}{l}\text { None } \\
\text { indicated in } \\
\text { proceedings }\end{array}$ & $\begin{array}{l}\text { (1)TW Ollie } \\
\text { (2) RA } \\
\text { Stamper }\end{array}$ & $\begin{array}{l}\text { (1) DE Avison } \\
\text { (2) B Glasson } \\
\text { (3) G Shanks }\end{array}$ & $\begin{array}{l}\text { (1) R Hirscheim, } \\
\text { Klein, Lyyttinen } \\
\text { (2) GFitzgerald } \\
\text { (3) SIngram }\end{array}$ & $\begin{array}{l}\text { (1) RD Galliers } \\
\text { (2) M Shanahan } \\
\text { (3) K Kumar }\end{array}$ & $\begin{array}{c}\text { (1) L } \\
\text { Willcocks } \\
\text { (2) G Burke }\end{array}$ & $\begin{array}{c}\text { (1) MC } \\
\text { Jackson } \\
\text { (2) K Myers }\end{array}$ & \\
\hline \# of delegates & & & & & $120^{* \star}$ & $169^{\star \star \star}$ & & & \\
\hline $\begin{array}{r}\text { doctoral } \\
\text { consortium }\end{array}$ & & & & & & $26^{\text {th }}$ Sept & & & \\
\hline \multicolumn{10}{|l|}{$\begin{array}{r}\text { \# consortium } \\
\text { students }\end{array}$} \\
\hline $\begin{array}{r}\text { consortium } \\
\text { chair(s) }\end{array}$ & & & & & & $\begin{array}{l}\text { P Marshall } \\
\text { J McKay }\end{array}$ & M Vitale & $\begin{array}{c}\mathrm{M} \\
\text { Broadbent }\end{array}$ & M O'Connor \\
\hline
\end{tabular}


Table 3b. Australasian Conference on Information Systems: 1998-2005

\begin{tabular}{|c|c|c|c|c|c|c|c|c|c|}
\hline Year & 1999 & 2000 & 2001 & 2002 & 2003 & 2004 & 2005 & 2006 & 2007 \\
\hline City & Wellington & Brisbane & Coffs Harbour & Melbourne & Perth & Hobart & Sydney & Adelaide & Toowoomba \\
\hline Sponsoring $U$. & $\begin{array}{l}\text { Victoria U. of } \\
\text { Wellington }\end{array}$ & \begin{tabular}{|} 
Queensland \\
U. of \\
Technology
\end{tabular} & $\begin{array}{c}\text { Southern Cross } \\
\text { U. }\end{array}$ & Victoria U. & $\begin{array}{c}\text { Edith Cowan } \\
\text { U. }\end{array}$ & $\begin{array}{c}\text { U. of } \\
\text { Tasmania }\end{array}$ & $\begin{array}{l}\text { U Technology } \\
\text { Sydney }\end{array}$ & $\begin{array}{l}\text { U South } \\
\text { Australia }\end{array}$ & $\begin{array}{l}\text { U Southern } \\
\text { Queensland }\end{array}$ \\
\hline program chair(s) & $\begin{array}{l}\text { BHope } \\
\text { PYoong }\end{array}$ & $\begin{array}{l}\text { GGable } \\
\text { MVitale }\end{array}$ & $\begin{array}{c}\text { DCecez- } \\
\text { Kecmanovic } \\
\text { GFinnie }\end{array}$ & $\begin{array}{l}\text { MMcGrath } \\
\text { FBurstein } \\
\text { AWenn } \\
\end{array}$ & $\begin{array}{l}\text { CStanding } \\
\text { PLove }\end{array}$ & \begin{tabular}{|c|} 
SElliot \\
M-AWilliams \\
SWilliams \\
\end{tabular} & $\begin{array}{l}\text { BCampbell } \\
\text { DBunker }\end{array}$ & EFitzgerald & MToleman \\
\hline $\begin{array}{r}\text { conference } \\
\text { chair(s) }\end{array}$ & David Keane & & Bruce Lo & Arthur Tatnall & Janice Burn & Carol Pollard & David Wilson & $\begin{array}{l}\text { AKoronios } \\
\text { SSpencer }\end{array}$ & DRoberts \\
\hline $\begin{array}{r}\text { organising } \\
\text { chair(s) }\end{array}$ & & $\begin{array}{c}\text { Alan } \\
\text { Underwood }\end{array}$ & & Geoff Sandy & $\begin{array}{c}\text { Nick } \\
\text { Lethbridge }\end{array}$ & Leonie Ellis & $\begin{array}{c}\text { Jim } \\
\text { Underwood }\end{array}$ & & ACater-Steel \\
\hline dates & $1-3 \mathrm{Dec}$ & 6-8 Dec & $5-7 \mathrm{Dec}$ & 4-6 Dec & 26-28 Nov & $1-3 \mathrm{Dec}$ & Nov30-Dec2 & 6-8 Dec & 5-7 Dec \\
\hline duration & 3 days & & 3 days & 3 days & 3 days & 3 days & 3 days & 3 days & 3 days \\
\hline \# submissions & & 180 & 165 & 151 & 246 & 227 & 262 & 218 & \\
\hline $\begin{array}{r}\text { \# countries (1st } \\
\text { author) }\end{array}$ & 8 & 13 & 6 & 9 & 11 & 9 & 11 & 20 & \\
\hline acceptance rate & $53 \%$ & $50 \%$ & $52 \%$ & $67 \%$ & $60 \%$ & $53 \%$ & $43 \%$ & $53 \%$ & \\
\hline parallel streams & 4 & & & 4 & 6 & 3 & 6 & 5 & \\
\hline $\begin{array}{r}\text { papers in } \\
\text { proceedings }\end{array}$ & 103 & 94 & 86 & 104 & 147 & 120 & 113 & 114 & \\
\hline panels & & 6 & 8 & 6 & 7 & 5 & & & \\
\hline tutorials & & & & & & & 3 workshops & & \\
\hline $\begin{array}{r}\text { Keynote and } \\
\text { invited speakers }\end{array}$ & $\begin{array}{c}\text { (1) RB Gallupe } \\
\text { (2) MLMarkus (3) } \\
\text { RNorris }\end{array}$ & $\begin{array}{l}\text { (1) DAvison } \\
\text { (2) Gordon } \\
\text { Davis }\end{array}$ & $\begin{array}{l}\text { (1) PCoroneos (2) } \\
\text { EMTrauth (3) } \\
\text { MVitale }\end{array}$ & $\begin{array}{c}\text { (1)B Jones } \\
\text { (2)M Broadbent } \\
\text { (3)C Bennett } \\
\text { (4)W Wojtkowski }\end{array}$ & $\begin{array}{l}\text { (1) NBjorn- } \\
\text { Andersen (2) } \\
\text { Dvogel (3) } \\
\text { VAdamson }\end{array}$ & (1) BGalliers & $\begin{array}{l}\text { (1) DGwillim (2) } \\
\text { KKautz }\end{array}$ & $\begin{array}{l}\text { (1)PGrant } \\
\text { (2)JPeppard } \\
\text { (3)GGable }\end{array}$ & \\
\hline \# of delegates & & 250 & 220 & 283 & 255 & 236 & & 185 & \\
\hline $\begin{array}{r}\text { doctoral } \\
\text { consortium }\end{array}$ & & & $4^{\text {th }} \mathrm{Dec}$ & & 25th Nov & 30th Nov & Nov 30-Dec 2 & 4-5 Dec & $4 \mathrm{Dec}$ \\
\hline $\begin{array}{r}\text { \# consortium } \\
\text { students }\end{array}$ & & & 32 & 23 & 29 & 28 & & 18 & \\
\hline $\begin{array}{r}\text { consortium } \\
\text { chair(s) }\end{array}$ & Bob McQueen & $\begin{array}{c}\text { Michael } \\
\text { Myers }\end{array}$ & Kit Dampney & Mike Metcalfe & $\begin{array}{l}\text { Graham } \\
\text { Pervan }\end{array}$ & Sid Huff & $\begin{array}{c}\text { IHawryszkiewy } \\
\text { cz }\end{array}$ & J. Fisher & GGable \\
\hline
\end{tabular}


in universities in Australia, a tabular form (Table 4$)^{14}$ was sent to senior IS academics at each university in Australia.

Table 4. Administrative Placement of IS Survey Instrument

\begin{tabular}{|c|c|c|c|c|c|c|c|c|}
\hline \multirow[b]{4}{*}{ University } & \multicolumn{4}{|c|}{ Location of IS within the University } & \multicolumn{4}{|c|}{ Generic Levels with the University } \\
\hline & & 2nd & $3 r d$ & 4th & & 2nd & $3 r d$ & 4th \\
\hline & 1st Level & Level & Level & Level & 1st Level & Level & Level & Level \\
\hline & Down & Down & Down & Down & Down & Down & Down & Down \\
\hline e.g. QUT & $\begin{array}{c}\text { Faculty } \\
\text { of IT }\end{array}$ & $\begin{array}{c}\text { School } \\
\text { of IS }\end{array}$ & & & Faculty & School & & \\
\hline & & & & & & & & \\
\hline & & & & & & & & \\
\hline & & & & & & & & \\
\hline
\end{tabular}

Tables 5-12 show the results of the survey for universities in individual states and territories. The overall results of the survey are discussed in Section IV. Universities are also coded in Tables 512 by era, where (refer Table 2):

$\begin{array}{lll}\text { - } & \mathrm{SS}= & \text { Sandstone (pre WWI) } \\ \text { - } & \mathrm{RB}= & \text { Red Brick (1940s-50s) } \\ \text { - } & \mathrm{GT}= & \text { Gum Tree (60s to mid-70s) } \\ \text { - } & \mathrm{UT}= & \text { Unitech ((former Institutes of Technology) } \\ \text { - } & \mathrm{NU}= & \text { New University (post 1987) } \\ \text { - } & \mathrm{PU}= & \text { Private University }\end{array}$

Universities were further coded in Tables 5-12 by the "type" of faculty in which IS was located, where:

- $\quad B=\quad$ "Business," faculties which are called business, economics or commerce.

- $\quad \mathrm{T}=$ "Technology," including faculties that called science, information technology, or engineering.

- $\quad 2=\quad$ "Both," referring to universities that have an information systems group in both the "business" and the "technology" faculty types.

- $\quad \mathrm{C}=$ "Combined," where the university has a combined faculty called something like business and technology.

- $\mathrm{O}=\quad$ "Other," indicating that IS is situated in some other type of faculty such as arts.

Several universities reported that they were in the process of restructuring, so these counts should not be regarded as fixed.

Note that Australian Catholic University considers it is national rather than state-based and thus has not been associated with any single state or territory. That being said, it is also noted that many of the state-based universities have substantial activities in other than their home states. A separate case study of the Northern Territory (NT) was not conducted due to the limited Information Systems activity in its sole university - Charles Darwin University, and our inability to locate a champion of an NT case study. Table 5 thus lists details of the placement of Information Systems activity at each of the aforementioned two universities.

\footnotetext{
${ }^{14}$ includes the example of Queensland University of Technology (QUT)
} 
Table 5. Placement of the IS Academic Discipline in Australian Catholic University and Charles

Darwin University

\begin{tabular}{|c|c|c|c|c|c|c|c|c|c|}
\hline \multirow[b]{2}{*}{ 茪 } & \multirow{2}{*}{$\overbrace{}^{\circ}$} & \multirow[b]{2}{*}{ University } & \multicolumn{4}{|c|}{ Location of IS within the University } & \multicolumn{3}{|c|}{ Generic Levels } \\
\hline & & & $\begin{array}{c}\text { 1st Level } \\
\text { Down }\end{array}$ & $\begin{array}{c}\begin{array}{c}\text { 2nd Level } \\
\text { Down }\end{array} \\
\end{array}$ & $\begin{array}{l}\text { 3rd Level } \\
\text { Down }\end{array}$ & $\begin{array}{l}\text { 4th Level } \\
\text { Down }\end{array}$ & \begin{tabular}{c|c|} 
1st \\
Level
\end{tabular} & $\begin{array}{l}\text { 2nd } \\
\text { Level }\end{array}$ & $\begin{array}{c}\text { 3rd } \\
\text { Level }\end{array}$ \\
\hline \multicolumn{10}{|c|}{$\begin{array}{l}\text { Type (Faculty Type where IS resides) = B=Business, T=Technology, O=Other (e.g. Arts), 2=Both (Has IS groups in both B and T), C=Combined (Has B } \\
\text { \&T in a single faculty) ... Era = SS=Sandstone, RB=Redbrick, GT=Gumtrees, UT=Unitech, NU=New University, PU=Private University }\end{array}$} \\
\hline \multicolumn{10}{|c|}{ Multi-State } \\
\hline NU & O & $\begin{array}{c}\text { Australian Catholic } \\
\text { University }\end{array}$ & $\begin{array}{l}\text { Faculty of Arts and } \\
\text { Sciences }\end{array}$ & $\begin{array}{l}\text { School of Business } \\
\text { and Informatics } \\
\text { (VIC) (QLD) } \\
\text { (NSW) }\end{array}$ & (IS group) & & Faculty & School & \\
\hline \multicolumn{10}{|c|}{ Northern Territory (NT) } \\
\hline NU & $\mathrm{T}$ & $\begin{array}{l}\text { Charles Darwin } \\
\text { University }\end{array}$ & Faculty of Tech. & $\begin{array}{c}\text { School of } \\
\text { Information Tech. }\end{array}$ & (IS group) & & Faculty & School & Discipline \\
\hline
\end{tabular}

\section{IS IN QUEENSLAND: A CASE STUDY}

Smyth and Gable [2006] gathered data from all nine universities in Queensland including the state campus of the Australian Catholic University. Relative to its population of 4 million, Queensland has a large number of universities, and all are engaged in Information Systems teaching and research. Five Queensland universities report IS groups of 15 or more academics and IS student populations of over 1,000. Table 6 following shows that across the nine universities there is wide variability in terms of the administrative location of the Information Systems academic staff in the university structure.

There is little evidence of Information Systems curriculum or research effort being focused on accommodating local community characteristics in Queensland. While the study does show a considerable diversity of curriculum approaches and an equally broad range of research topics and research methods across the nine universities, there was little sign of sharply different "philosophies" of Information Systems. In general, the curricula and research emphases of the Queensland universities showed an eclectic melding of various European and American approaches. Only at University of Queensland and at Griffith University, both of which maintain two strong Information Systems groups, one "technical" and the other "business-focused," is a blending of approaches to Information Systems not in place in a single administrative unit.

The study assessed the state of IS in Queensland universities in relation to criteria indicative of the maturity of a discipline. Measured against these criteria, Information Systems in Queensland universities cannot yet be considered a mature, distinct academic discipline. However, one of the criteria for discipline maturity, that those in the discipline have the potential for prestige and power through prominence in that discipline, has perhaps been met, with several senior Information Systems academics recognized by their Queensland universities as full professors of Information Systems. 
Table 6. Placement of the IS Academic Discipline in QLD Universities

\begin{tabular}{|c|c|c|c|c|c|c|c|c|c|}
\hline \multirow[b]{2}{*}{ 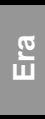 } & \multirow{2}{*}{$\stackrel{1}{2}$} & \multirow[b]{2}{*}{ University } & \multicolumn{4}{|c|}{ Location of IS within the University } & \multicolumn{3}{|c|}{ Generic Levels } \\
\hline & & & \begin{tabular}{c|c|c|c|} 
1st Level & \\
Down &
\end{tabular} & $\begin{array}{c}\text { 2nd Level } \\
\text { Down }\end{array}$ & $\begin{array}{c}\text { 3rd Level } \\
\text { Down }\end{array}$ & $\begin{array}{l}\text { 4th Level } \\
\text { Down }\end{array}$ & $\begin{array}{c}1 \text { 1st } \\
\text { Level }\end{array}$ & $\begin{array}{c}\text { 2nd } \\
\text { Level }\end{array}$ & $\begin{array}{c}\text { 3rd } \\
\text { Level }\end{array}$ \\
\hline \multicolumn{10}{|c|}{$\begin{array}{l}\text { Type (Faculty Type where IS resides) = B=Business, T=Technology, O=Other (e.g. Arts), 2=Both (Has IS groups in both B and T), C=Combined (Has B \& } \\
\text { in a single faculty) ... Era = SS=Sandstone, RB=Redbrick, GT=Gumtrees, UT=Unitech, NU=New University, PU=Private University }\end{array}$} \\
\hline \multicolumn{10}{|c|}{ Queensland (QLD) } \\
\hline PU & C & Bond University & $\begin{array}{c}\text { Faculty of Business, } \\
\text { Tech. and } \\
\text { Sustainable } \\
\text { Development } \\
\end{array}$ & $\begin{array}{c}\text { School of } \\
\text { Information Tech. }\end{array}$ & $\begin{array}{l}\text { Information } \\
\text { Systems } \\
\text { Dept }\end{array}$ & & Faculty & School & Dept \\
\hline NU & C & $\begin{array}{c}\text { Central Queensland } \\
\text { University }\end{array}$ & $\begin{array}{c}\text { Faculty of Business } \\
\text { \& Informatics }\end{array}$ & $\begin{array}{l}\text { School of } \\
\text { Information } \\
\text { Systems } \\
\end{array}$ & & & Faculty & School & \\
\hline GT & 2 & Griffith University & Business (group) & $\begin{array}{l}\text { Griffith Business } \\
\text { School }\end{array}$ & $\begin{array}{c}\text { Dept of } \\
\text { Mgmt }\end{array}$ & (IS group) & Group & $\begin{array}{l}\text { School } \\
\text { (only in } \\
\text { Business) } \\
\text { or Faculty }\end{array}$ & $\begin{array}{c}\text { Dept } \\
\text { (only in } \\
\text { Business) }\end{array}$ \\
\hline GT & 2 & Griffith University & $\begin{array}{c}\text { Griffith Science and } \\
\text { Tech. (group) }\end{array}$ & $\begin{array}{c}\text { Faculty of } \\
\text { Engineering and } \\
\text { Information Tech. }\end{array}$ & $\begin{array}{c}\text { School of } \\
\text { Information } \\
\text { and Comm. } \\
\text { Tech. }\end{array}$ & (IS group) & Group & Faculty & School \\
\hline GT & B & $\begin{array}{c}\text { James Cook } \\
\text { University }\end{array}$ & $\begin{array}{l}\text { Faculty of Law } \\
\text { Business and } \\
\text { Creative Arts }\end{array}$ & School of Business & $\begin{array}{c}\text { Accounting } \\
\text { and Finance } \\
\text { Program } \\
\end{array}$ & (IS group) & Faculty & School & Program \\
\hline UT & $\mathrm{T}$ & $\begin{array}{c}\text { Queensland } \\
\text { University of } \\
\text { Technology }\end{array}$ & $\begin{array}{c}\text { Faculty of } \\
\text { Information Tech. }\end{array}$ & $\begin{array}{c}\text { School of } \\
\text { Information } \\
\text { Systems }\end{array}$ & & & Faculty & School & \\
\hline SS & 2 & $\begin{array}{l}\text { University of } \\
\text { Queensland }\end{array}$ & $\begin{array}{c}\text { Faculty of } \\
\text { Engineering, } \\
\text { Physical Scences } \\
\text { and Architecture }\end{array}$ & $\begin{array}{c}\text { School of } \\
\text { Information } \\
\text { Technology and } \\
\text { Electrical } \\
\text { Engineering } \\
\end{array}$ & \begin{tabular}{|c|} 
Data and \\
Knowledge \\
Engineering \\
Research \\
Division \\
\end{tabular} & & Faculty & School & $\begin{array}{l}\text { Research } \\
\text { Division }\end{array}$ \\
\hline SS & 2 & $\begin{array}{l}\text { University of } \\
\text { Queensland }\end{array}$ & $\begin{array}{c}\text { Faculty of Business, } \\
\text { Economics, and } \\
\text { Law } \\
\end{array}$ & UQ Business School & (IS group) & & Faculty & School & Discipline \\
\hline $\mathrm{NU}$ & B & $\begin{array}{l}\text { University of } \\
\text { Southern } \\
\text { Queensland }\end{array}$ & Faculty of Business & $\begin{array}{c}\text { Dept of Information } \\
\text { Systems }\end{array}$ & & & Faculty & Dept & \\
\hline NU & B & $\begin{array}{l}\text { University of the } \\
\text { Sunshine Coast }\end{array}$ & Faculty of Business & $\begin{array}{c}\text { School of } \\
\text { Commerce } \\
\text { (Accounting and } \\
\text { Information } \\
\text { Systems) } \\
\end{array}$ & $\begin{array}{l}\text { Information } \\
\text { Systems } \\
\text { Discipline }\end{array}$ & & Faculty & School & \\
\hline
\end{tabular}

\section{IS IN AUSTRALIAN CAPITAL TERRITORY (ACT): A CASE STUDY}

The Australian Capital Territory is less than 100 square kilometres in size and almost all of its population of 300,000 lives in the city of Canberra, Australia's national capital. Gregor, Lewis and McDonald [2006] prepared the case study report for the ACT. Each of these three leaders in IS represents one of the territory's three universities: Australian National University (ANU), University of Canberra (UC), and the Australian Defence Force Academy (University of New South Wales - ADFA). IS is well established at all three universities, each having a distinctive background that reflects its position in Australia's seat of federal government. The Australian Defence Force Academy is essentially a private university for the Australian Defence Organization; the Australian National University was set up to be a national research institution; and the University of Canberra IS group for many years focused on meeting the training needs for computing professionals for the federal government. Despite these distinguishing characteristics, the subject matter taught and researched in the three IS groups has a large degree of 
commonality. The report depicts a vibrant IS group in each university but indicates concern with the disparate administrative locations of the IS academics (see Table 7) and the relative lack of a strong identity for IS within the universities. A low degree of "professionalisation" is perceived relative to older disciplines as there is: a disjoint between what is taught as core knowledge and what is taught as research methods, a lack of social prestige, and a lack of acceptance as a discipline with a unique symbol system.

Table 7. Placement of the IS Academic Discipline in ACT Universities

\begin{tabular}{|c|c|c|c|c|c|c|c|c|c|}
\hline \multirow{2}{*}{ 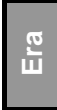 } & \multirow{2}{*}{ 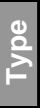 } & \multirow[b]{2}{*}{ University } & \multicolumn{4}{|c|}{ Location of IS within the University } & \multicolumn{3}{|c|}{ Generic Levels } \\
\hline & & & $\begin{array}{l}\text { 1st Level } \\
\text { Down }\end{array}$ & $\begin{array}{l}\text { 2nd Level } \\
\text { Down }\end{array}$ & $\begin{array}{c}\text { 3rd Level } \\
\text { Down }\end{array}$ & $\begin{array}{l}\text { 4th Level } \\
\text { Down }\end{array}$ & $\begin{array}{c}\text { 1st } \\
\text { Level }\end{array}$ & $\begin{array}{l}\text { 2nd } \\
\text { Level }\end{array}$ & $\begin{array}{c}\text { 3rd } \\
\text { Level }\end{array}$ \\
\hline \multicolumn{10}{|c|}{$\begin{array}{l}\text { Type (Faculty Type where IS resides) = B=Business, T=Technology, O=Other (e.g. Arts), 2=Both (Has IS groups in both B and T), C=Combined (Has B \&T } \\
\text { in a single faculty) ... Era = SS=Sandstone, RB=Redbrick, GT=Gumtrees, UT=Unitech, NU=New University, PU=Private University }\end{array}$} \\
\hline \multicolumn{10}{|c|}{ Australian Capital Territory (ACT) } \\
\hline RB & B & $\begin{array}{c}\text { Australian National } \\
\text { University }\end{array}$ & $\begin{array}{l}\text { College of Business } \\
\text { and Economics }\end{array}$ & $\begin{array}{c}\text { School of } \\
\text { Accounting and } \\
\text { Business } \\
\text { Information } \\
\text { Systems }\end{array}$ & $\begin{array}{l}\text { Information } \\
\text { Systems } \\
\text { Discipline } \\
\text { Group }\end{array}$ & & College & School & Discipline \\
\hline NU & C & $\begin{array}{l}\text { University of } \\
\text { Canberra }\end{array}$ & $\begin{array}{c}\text { Division of } \\
\text { Business, Law and } \\
\text { Information } \\
\text { Sciences }\end{array}$ & $\begin{array}{c}\text { School of } \\
\text { Information } \\
\text { Sciences and } \\
\text { Engineering }\end{array}$ & $\begin{array}{l}\text { Information } \\
\text { Systems } \\
\text { Discipline }\end{array}$ & & Division & School & Discipline \\
\hline RB & $\mathrm{T}$ & $\begin{array}{c}\text { University of NSW } \\
\text { (ADFA) }\end{array}$ & $\begin{array}{l}\text { Australian Defence } \\
\text { Force Academy }\end{array}$ & $\begin{array}{l}\text { School of IT and } \\
\text { Electrical } \\
\text { Engineering }\end{array}$ & (IS group) & & Faculty & School & \\
\hline
\end{tabular}

\section{IS IN NEW SOUTH WALES (NSW): A CASE STUDY}

Underwood and Jordan [2006] examined Information Systems in universities in the most populous state in Australia, New South Wales. Even though the Information and Communications Technology (ICT) industry is a significant part of the NSW economy, and there are longestablished university programs that support this economy, IS in NSW is not thriving. Rather than offering comprehensive coverage of all Information Systems courses in the state's 10 universities, Underwood and Jordan provide a broad overview of Information Systems in the state while highlighting the distinctive characteristics of five universities that were deemed to have particular prominence in IS. The universities that are reported in detail are: the University of New South Wales, the University of Sydney, Wollongong University, the University of Technology Sydney and Charles Sturt University.

In New South Wales, students undertaking strongly identified IS undergraduate degrees can only be found at the University of New South Wales. At other universities IS is generally a major in other programs; the size of the IS presence therefore dependent upon the university's enrolment in the core programs that offer IS majors. IS academics are thus often dispersed across several departments or faculties. The growth of enrolments in commerce over the last 20 years has advantaged those IS units that are located in that faculty.

The administrative placement of IS in New South Wales universities can be seen in Table 8. Only four universities have some structural recognition of IS as a separate field. Most IS groups remain as ad hoc or informal groups within larger departments.

Research in the state's universities is characterised by diversity and limited collaboration. While large IS research projects were recorded at the University of New South Wales, the University of Sydney and the University of Technology Sydney, such large projects were otherwise few in number. 
Table 8. Placement of the IS Academic Discipline in NSW Universities

\begin{tabular}{|c|c|c|c|c|c|c|c|c|c|}
\hline \multirow[b]{2}{*}{ i⿱一⿻上丨乚 } & \multirow{2}{*}{$\sum_{1}^{\infty}$} & \multirow[b]{2}{*}{ University } & \multicolumn{4}{|c|}{ Location of IS within the University } & \multicolumn{3}{|c|}{ Generic Levels } \\
\hline & & & \begin{tabular}{l|l|} 
1st Level & \\
Down
\end{tabular} & $\begin{array}{c}\text { 2nd Level } \\
\text { Down }\end{array}$ & \begin{tabular}{c|c|}
$\begin{array}{c}\text { 3rd Level } \\
\text { Down }\end{array}$ \\
\end{tabular} & $\begin{array}{l}\text { 4th Level } \\
\text { Down }\end{array}$ & 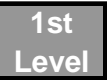 & \begin{tabular}{c|c|} 
2nd \\
Level
\end{tabular} & $\begin{array}{c}\text { 3rd } \\
\text { Level }\end{array}$ \\
\hline \multicolumn{10}{|c|}{$\begin{array}{l}\text { Type (Faculty Type where IS resides) = B=Business, T=Technology, O=Other (e.g. Arts), 2=Both (Has IS groups in both B and T), C=Combined (Has B } \\
\text { \&T in a single faculty) ... Era = SS=Sandstone, RB=Redbrick, GT=Gumtrees, UT=Unitech, NU=New University, PU=Private University }\end{array}$} \\
\hline \multicolumn{10}{|c|}{ New South Wales (NSW) } \\
\hline NU & C & \begin{tabular}{|c|} 
Charles Sturt \\
University (Albury) \\
from 2007 \\
\end{tabular} & $\begin{array}{c}\text { Faculty of Business } \\
\text { and Computing }\end{array}$ & $\begin{array}{c}\begin{array}{c}\text { School of Business } \\
\text { and Information } \\
\text { Tech. }\end{array} \\
\end{array}$ & (IS group) & & & & \\
\hline NU & C & $\begin{array}{c}\text { Charles Sturt } \\
\text { University (Wagga } \\
\text { Wagga) from } 2007\end{array}$ & $\begin{array}{c}\text { Faculty of Business } \\
\text { and Computing } \\
\text { (proposed name) }\end{array}$ & $\begin{array}{c}\text { School of } \\
\text { Computing and } \\
\text { Mathematics } \\
\text { (proposed name) }\end{array}$ & (IS group) & & Faculty & School & \\
\hline GT & 2 & $\begin{array}{l}\text { Macquarie } \\
\text { University }\end{array}$ & $\begin{array}{c}\text { College of Science } \\
\text { and Tech. }\end{array}$ & $\begin{array}{c}\text { Division of } \\
\text { Information and } \\
\text { Comm. Sciences } \\
\end{array}$ & $\begin{array}{c}\text { Dept of } \\
\text { Computing }\end{array}$ & (IS group) & College & Division & Dept \\
\hline GT & 2 & $\begin{array}{l}\text { Macquarie } \\
\text { University }\end{array}$ & $\begin{array}{l}\text { College of } \\
\text { Commerce }\end{array}$ & $\begin{array}{c}\text { Division of } \\
\text { Economics and } \\
\text { Financial Studies }\end{array}$ & $\begin{array}{c}\text { Dept of } \\
\text { Accounting } \\
\text { and Finance } \\
\end{array}$ & (IS group) & College & Division & Dept \\
\hline GT & 2 & $\begin{array}{l}\text { Macquarie } \\
\text { University }\end{array}$ & $\begin{array}{l}\text { College of } \\
\text { Commerce }\end{array}$ & $\begin{array}{c}\text { Macquarie } \\
\text { Graduate School of } \\
\text { Mgmt }\end{array}$ & (IS) & & College & Division & Dept \\
\hline NU & B & $\begin{array}{c}\text { Southern Cross } \\
\text { University }\end{array}$ & Faculty of Business & $\begin{array}{c}\text { School of } \\
\text { Commerce and } \\
\text { Mgmt }\end{array}$ & (IS group) & & Faculty & School & \\
\hline GT & B & $\begin{array}{c}\text { University of New } \\
\text { England }\end{array}$ & $\begin{array}{c}\text { Faculty of } \\
\text { Economics, } \\
\text { Business and Law }\end{array}$ & $\begin{array}{l}\text { New England } \\
\text { Business School }\end{array}$ & (IS) & & Faculty & School & \\
\hline GT & $\mathrm{T}$ & $\begin{array}{l}\text { University of } \\
\text { Newcastle }\end{array}$ & $\begin{array}{c}\text { Faculty of Science } \\
\text { and Information } \\
\text { Tech. }\end{array}$ & $\begin{array}{l}\text { School of Design } \\
\text { Comm. and } \\
\text { Information Tech. }\end{array}$ & $\begin{array}{l}\text { Information } \\
\text { Tech. } \\
\text { Discipline } \\
\end{array}$ & (IS group) & Faculty & School & Discipline \\
\hline RB & B & University of NSW & $\begin{array}{l}\text { Faculty of } \\
\text { Commerce and } \\
\text { Economics }\end{array}$ & $\begin{array}{c}\text { School of } \\
\text { Information } \\
\text { Systems, Tech. and } \\
\text { Mgmt }\end{array}$ & (IS group) & & Faculty & School & \\
\hline SS & 2 & $\begin{array}{c}\text { University of } \\
\text { Sydney }\end{array}$ & Faculty of Science & $\begin{array}{c}\text { School of } \\
\text { Information } \\
\text { Technologies } \\
\end{array}$ & (IS group) & & & & \\
\hline SS & 2 & $\begin{array}{l}\text { University of } \\
\text { Sydney }\end{array}$ & $\begin{array}{c}\text { Faculty of } \\
\text { Economics and } \\
\text { Business }\end{array}$ & School of Business & 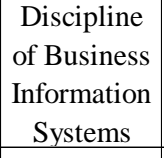 & & Faculty & School & Discipline \\
\hline UT & $\mathrm{T}$ & $\begin{array}{c}\text { University of Tech. } \\
\text { Sydney }\end{array}$ & $\begin{array}{c}\text { Faculty of } \\
\text { Information Tech. }\end{array}$ & $\begin{array}{c}\text { Dept of Information } \\
\text { Systems }\end{array}$ & & & Faculty & $\begin{array}{c}\text { School } \\
\text { (only in the } \\
\text { Business } \\
\text { Faculty) or } \\
\text { Dept }\end{array}$ & \\
\hline NU & 2 & \begin{tabular}{|c|} 
University of \\
Western Sydney (E- \\
Business) \\
\end{tabular} & College of Business & School of Mgmt & $\begin{array}{c}\text { Business } \\
\text { Systems } \\
\text { Group } \\
\end{array}$ & & College & School & \\
\hline $\mathrm{NU}$ & 2 & $\begin{array}{c}\text { University of } \\
\text { Western Sydney } \\
\text { (IS) } \\
\end{array}$ & $\begin{array}{l}\text { College of Health } \\
\text { and Science }\end{array}$ & $\begin{array}{c}\text { School of } \\
\text { Computing and } \\
\text { Mathematics }\end{array}$ & (IS group) & & College & School & \\
\hline GT & B & $\begin{array}{l}\text { University of } \\
\text { Wollongong }\end{array}$ & $\begin{array}{l}\text { Faculty of } \\
\text { Commerce }\end{array}$ & $\begin{array}{c}\text { School of } \\
\text { Economics and } \\
\text { Information } \\
\text { Systems } \\
\end{array}$ & $\begin{array}{c}\text { Discipline } \\
\text { of } \\
\text { Information } \\
\text { Systems } \\
\end{array}$ & & Faculty & School & \\
\hline
\end{tabular}


The overall view portrayed was of an environment where the continuing existence of Information Systems in some of the state's universities is under threat. IS in most NSW universities is viewed as having failed to develop an identity or a presence.

\section{IS IN SOUTH AUSTRALIA (SA): A CASE STUDY}

The state of South Australia includes some of the most arid parts of Australia and the majority of its population of 1.5 million resides in the state capital, Adelaide. A feature of Koronios and Swatman's [2006] study of the state of IS in South Australian universities is that it reveals a concentration of IS in just one university; the University of South Australia. Only a minimal presence of IS exists in the other two SA universities.

On the basis that Information Systems degrees in South Australia are offered only at the University of South Australia, the South Australian study, by definition, becomes a study of IS at that university. The study suggests that the state of South Australia's IS offerings were heavily influenced during the 1990s by the soft systems and critical systems approaches to the discipline, a situation which began to change only at the turn of the century. The study also suggests that both curriculum and research in IS in South Australia have been influenced heavily by the specific industrial make-up of that state.

The administrative placement of IS in the three South Australian universities can be seen in Table 9. Even at the University of South Australia which has the strongest IS presence there is no administrative acknowledgement of IS. Information systems was acknowledged as a separate field at the University of South Australia when it was part of business but is less clearly delineated now that it is part of a large, combined computing school. IS appears to be losing ground in South Australia and this to a large degree can be traced to a comparative lack of local student interest in IS.

Table 9. Placement of the IS Academic Discipline in SA Universities

\begin{tabular}{|c|c|c|c|c|c|c|c|c|c|}
\hline \multirow[b]{2}{*}{ 要 } & \multirow{2}{*}{$\stackrel{0}{2}$} & \multirow[b]{2}{*}{ University } & \multicolumn{4}{|c|}{ Location of IS within the University } & \multicolumn{3}{|c|}{ Generic Levels } \\
\hline & & & \begin{tabular}{|c|} 
1st Level \\
Down
\end{tabular} & \begin{tabular}{|c|}
$\begin{array}{c}\text { 2nd Level } \\
\text { Down }\end{array}$ \\
\end{tabular} & $\begin{array}{c}\text { 3rd Level } \\
\text { Down }\end{array}$ & $\begin{array}{l}\text { 4th Level } \\
\text { Down }\end{array}$ & \begin{tabular}{|c|} 
1st \\
Level
\end{tabular} & $\begin{array}{c}\text { 2nd } \\
\text { Level } \\
\end{array}$ & $\begin{array}{l}\text { 3rd } \\
\text { Level }\end{array}$ \\
\hline \multicolumn{10}{|c|}{$\begin{array}{l}\text { Type (Faculty Type where IS resides) = B=Business, T=Technology, O=Other (e.g. Arts), } 2=B \text { Both (Has IS groups in both B and T), C=Combined (Has B \& } \\
\text { in a single faculty) ... Era = SS=Sandstone, RB=Redbrick, GT=Gumtrees, UT=Unitech, NU=New University, PU=Private University }\end{array}$} \\
\hline \multicolumn{10}{|c|}{ South Australia (SA) } \\
\hline GT & $\mathrm{T}$ & Flinders University & $\begin{array}{l}\text { Faculty of Science } \\
\text { and Engineering }\end{array}$ & \begin{tabular}{|c|} 
School of \\
Informatics and \\
Engineering \\
\end{tabular} & (IS group) & & Faculty & $\begin{array}{l}\text { School or } \\
\text { Dept }\end{array}$ & \\
\hline \multirow{2}{*}{ SS } & \multirow{2}{*}{ B } & \multirow{2}{*}{$\begin{array}{l}\text { University of } \\
\text { Adelaide }\end{array}$} & \multirow{2}{*}{$\begin{array}{l}\text { Faculty of the } \\
\text { Professions }\end{array}$} & \multirow{2}{*}{$\begin{array}{l}\text { School of } \\
\text { Commerce }\end{array}$} & (IS group) & & \multirow{2}{*}{ Faculty } & \multirow{2}{*}{ School } & \\
\hline & & & & & (3 staff) & & & & \\
\hline UT & $\mathrm{T}$ & $\begin{array}{c}\text { University of South } \\
\text { Australia }\end{array}$ & $\begin{array}{c}\text { Division of } \\
\text { Information Tech., } \\
\text { Engineering and the } \\
\text { Environment. }\end{array}$ & $\begin{array}{c}\text { School of Computer } \\
\text { and Information } \\
\text { Science }\end{array}$ & (IS group) & & Division & School & \\
\hline
\end{tabular}

\section{IS IN TASMANIA (TAS): A CASE STUDY}

The island state of Tasmania has a population of fewer than half a million and just one university. Ridley's [2006b] Tasmanian case study is distinctive in several respects. Firstly, it reports on just one university (see Table 10.). Also, the data gathering approach applied is somewhat different. Where reports in the other states used interviews from one or two senior academics in each university, in Tasmania it was possible to draw on data from a wide range of academics, both current and former staff members from University of Tasmania. To this end, the interview guide associated with the case study protocol was adapted to develop a survey instrument suitable for gathering data from former staff members no longer resident in Tasmania. The survey instrument elicited lengthy and thoughtful responses, suggesting that its use could be extended in future studies without major detriment in terms of insights into the views of the respondents. The survey 
instrument could also be used effectively as preliminary to a follow-up telephone interview. The author of the Tasmania report is also the author of the framework developed for the overall case study protocol [Ridley 2006a].

These study findings suggest that an inverse relationship exists between the impact of local factors and the degree of professionalism in this IS setting; that is to say, the study suggests that a number of purely local factors have had substantial impact on the IS curriculum and research in the state, to the potential detriment of the professionalisation of the local IS academics.

The study highlighted an aspect of the current importance of international students to teaching and research in Australian universities. In this instance, the study highlighted the challenges and opportunities involved in teaching IS at an offshore campus.

Table 10. Placement of the IS Academic Discipline in TAS Universities

\begin{tabular}{|c|c|c|c|c|c|c|c|c|c|}
\hline \multirow[b]{2}{*}{ 㜽 } & \multirow{2}{*}{ 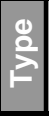 } & \multirow[b]{2}{*}{ University } & \multicolumn{4}{|c|}{ Location of IS within the University } & \multicolumn{3}{|c|}{ Generic Levels } \\
\hline & & & $\begin{array}{l}\text { 1st Level } \\
\text { Down }\end{array}$ & $\begin{array}{l}\text { 2nd Level } \\
\text { Down }\end{array}$ & $\begin{array}{l}\text { 3rd Level } \\
\text { Down }\end{array}$ & $\begin{array}{l}\text { 4th Level } \\
\text { Down }\end{array}$ & \begin{tabular}{c|c|c|} 
1st \\
Level
\end{tabular} & $\begin{array}{l}\text { 2nd } \\
\text { Level }\end{array}$ & $\begin{array}{l}\text { 3rd } \\
\text { Level }\end{array}$ \\
\hline \multicolumn{10}{|c|}{$\begin{array}{l}\text { Type (Faculty Type where IS resides) = B=Business, T=Technology, O=Other (e.g. Arts), 2=Both (Has IS groups in both B and T), C=Combined (Has B } \\
\text { \&T in a single faculty) ... Era = SS=Sandstone, RB=Redbrick, GT=Gumtrees, UT=Unitech, NU=New University, PU=Private University }\end{array}$} \\
\hline \multicolumn{10}{|c|}{ Tasmania (TAS) } \\
\hline SS & B & $\begin{array}{l}\text { University of } \\
\text { Tasmania }\end{array}$ & Faculty of Business & $\begin{array}{c}\text { School of } \\
\text { Information } \\
\text { Systems }\end{array}$ & & & Faculty & School & \\
\hline
\end{tabular}

\section{IS IN VICTORIA (VIC): A CASE STUDY}

Victoria, the smallest mainland state (3 percent of the land mass), is the most densely populated and urbanized state. Seventy percent of its population of over 5 million lives in Melbourne. Pollard and Chan's [2006] case study of IS in Victoria presents a fairly positive picture of IS in the state. All eight Victorian universities and the Melbourne campus of the Australian Catholic University offer IS programs and the majority of universities recognize Information Systems as a separate entity. Table 11 shows how the location of IS within the university structure differs by institution.

Universities in Victoria offer a wide range of undergraduate and postgraduate IS courses and programs. Though most academics expressed the view that local industry had had negligible influence on curriculum, universities in Victoria universally appear to be seeking increased collaboration with the local community and industry as part of their strategic direction. Distinctive themes taught within the many programs varied considerably. and included: Decision Analysis and Information Management (Monash); Global Information Systems (University of Ballarat); Electronic Commerce (Deakin); ERP (Victoria University); Design and Support of Business Processes (Swinburne); Educational Theory and Practice (LaTrobe); and Security, Decision Support, Usability and Interface Design (RMIT).

While research topics were diverse within the state, research methods were not. IS academics in Victoria appear to align themselves more closely with interpretivist European research traditions than with the quantitative, positivist approach more commonly found in North America. Relatively few IS departments have been successful in securing external grants from granting agencies such as the Australian Research Council and dwindling research funding is a problem for IS researchers in Victoria. Victoria, more than any other state, was heavily impacted by the Dawkins reforms to Australian tertiary education of the late 1980s and amalgamations and mergers at that time sometimes brought together strong IS groups with different cultures and different aspirations. 
Table 11. Placement of the IS Academic Discipline in VIC Universities

\begin{tabular}{|c|c|c|c|c|c|c|c|c|c|}
\hline \multirow[b]{2}{*}{ 部 } & \multirow{2}{*}{ 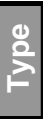 } & \multirow[b]{2}{*}{ University } & \multicolumn{4}{|c|}{ Location of IS within the University } & \multicolumn{3}{|c|}{ Generic Levels } \\
\hline & & & $\begin{array}{l}\text { 1st Level } \\
\text { Down }\end{array}$ & $\begin{array}{c}\text { 2nd Level } \\
\text { Down }\end{array}$ & \begin{tabular}{|c|c|}
$\begin{array}{c}\text { 3rd Level } \\
\text { Down }\end{array}$ \\
\end{tabular} & $\begin{array}{l}\text { 4th Level } \\
\text { Down }\end{array}$ & \begin{tabular}{|c|c|c|c|c|} 
1st \\
Level
\end{tabular} & \begin{tabular}{c|c|} 
2nd \\
Level
\end{tabular} & $\begin{array}{l}\text { 3rd } \\
\text { Level }\end{array}$ \\
\hline \multicolumn{10}{|c|}{$\begin{array}{l}\text { Type (Faculty Type where IS resides) = B=Business, T=Technology, O=Other (e.g. Arts), 2=Both (Has IS groups in both B and T), C=Combined (Has B } \\
\text { \&T in a single faculty) ... Era = SS=Sandstone, RB=Redbrick, GT=Gumtrees, UT=Unitech, NU=New University, PU=Private University }\end{array}$} \\
\hline \multicolumn{10}{|c|}{ Victoria (VIC) } \\
\hline GT & B & Deakin University & $\begin{array}{c}\text { Faculty of Business } \\
\text { and Law }\end{array}$ & $\begin{array}{l}\text { School of } \\
\text { Information } \\
\text { Systems }\end{array}$ & & & Faculty & School & \\
\hline GT & B & Deakin University & $\begin{array}{c}\text { Faculty of Business } \\
\text { and Law }\end{array}$ & $\begin{array}{l}\text { Deakin Business } \\
\text { School }\end{array}$ & $\begin{array}{c}\text { Information } \\
\text { Systems } \\
\text { Discipline } \\
\text { Group (3 } \\
\text { staff) }\end{array}$ & & Faculty & School & \\
\hline GT & $\mathrm{T}$ & La Trobe University & $\begin{array}{c}\text { Faculty of Science, } \\
\text { Tech. and } \\
\text { Engineering }\end{array}$ & $\begin{array}{c}\text { School of } \\
\text { Engineering and } \\
\text { Mathematical } \\
\text { Sciences }\end{array}$ & \begin{tabular}{|c|} 
Dept of \\
Computer \\
Science and \\
Computer \\
Engineering
\end{tabular} & (IS group) & Faculty & School & Dept \\
\hline $\mathrm{RB}$ & $\mathrm{T}$ & Monash University & $\begin{array}{c}\text { Faculty of } \\
\text { Information Tech. }\end{array}$ & $\begin{array}{l}\text { Caulfield School of } \\
\text { Information Tech. }\end{array}$ & (IS group) & & Faculty & School & \\
\hline $\mathrm{RB}$ & $\mathrm{T}$ & Monash University & $\begin{array}{c}\text { Faculty of } \\
\text { Information Tech. }\end{array}$ & $\begin{array}{l}\text { Clayton School of } \\
\text { Information Tech. }\end{array}$ & (IS group) & & Faculty & School & \\
\hline UT & B & RMIT University & Faculty of Business & $\begin{array}{c}\text { School of Business } \\
\text { IT }\end{array}$ & & & Faculty & School & \\
\hline NU & $\mathrm{T}$ & $\begin{array}{c}\text { Swinburne } \\
\text { University of Tech. }\end{array}$ & $\begin{array}{c}\text { Faculty of } \\
\text { Information and } \\
\text { Comm. } \\
\text { Technologies }\end{array}$ & $\begin{array}{c}\text { Information } \\
\text { Systems Academic } \\
\text { Group }\end{array}$ & & & Faculty & $\begin{array}{c}\text { Academic } \\
\text { Group }\end{array}$ & \\
\hline NU & $\mathrm{T}$ & $\begin{array}{c}\text { University of } \\
\text { Ballarat }\end{array}$ & $\begin{array}{c}\text { School of } \\
\text { Information Tech. } \\
\text { and Mathematical } \\
\text { Sciences } \\
\end{array}$ & (IS group) & & & School & & \\
\hline SS & $\mathrm{T}$ & $\begin{array}{l}\text { University of } \\
\text { Melbourne }\end{array}$ & Faculty of Science & $\begin{array}{c}\text { Dept of Information } \\
\text { Systems }\end{array}$ & & & Faculty & $\begin{array}{c}\text { School or } \\
\text { Dept }\end{array}$ & \\
\hline NU & B & Victoria University & $\begin{array}{c}\text { Faculty of Business } \\
\text { and Law }\end{array}$ & \begin{tabular}{|c|} 
School of \\
Information \\
Systems
\end{tabular} & & & Faculty & School & \\
\hline
\end{tabular}

\section{IS IN WEST AUSTRALIA (WA): A CASE STUDY}

Western Australia (WA) is the largest state in Australia, encompassing 2.5 million square kilometres. It is relatively isolated from the rest of Australia and has a population of just 2 million. Table 12 shows the five universities in Western Australia. Standing et al. [2006] conducted interviews with senior academics from Western Australia's four public universities to report on the state of IS in the state. While all four public universities are based in Perth, they all have a remit to service the whole state and, so, typically have remote campuses across WA. Additionally, all universities have substantial external offerings, which initially targeted the distant WA population but now recruit from a global community.

The main IS strength in WA lies in Curtin University of Technology and Edith Cowan University, where separate IS schools have been in existence for over 30 years. At the University of Western Australia and Murdoch University, IS is a sub-set of other disciplines and has a somewhat lower status.

The Western Australia report suggests that the state's isolation and relative remoteness from the universities elsewhere in Australia has impinged on the development of IS there. The core body 
of knowledge taught at each of the four universities tends to reflect local allegiances with industry, services and professions and varies in line with local developments and needs rather than necessarily responding directly to demands from within the discipline itself.

All four universities support both qualitative and quantitative research and employ multi-methods. Case studies and interpretive research are commonly applied. The research focus within the four universities is very different and this may be one of the reasons that all interviewees reported a low level of collaboration between WA Universities.

In WA, social processes and local contingencies seem to have had considerable impact on the development of the discipline. Standing et al. [2006, p.258] conclude that in WA "it would appear that IS is still 'a perspective' rather than a discipline and a perpetually shifting perspective at that."

Table 12. Placement of the IS Academic Discipline in WA Universities

\begin{tabular}{|c|c|c|c|c|c|c|c|c|c|}
\hline \multirow[b]{2}{*}{ 茪 } & \multirow{2}{*}{$\sum_{\substack{\infty \\
\hdashline}}^{\infty}$} & \multirow[b]{2}{*}{ University } & \multicolumn{4}{|c|}{ Location of IS within the University } & \multicolumn{3}{|c|}{ Generic Levels } \\
\hline & & & \begin{tabular}{c|} 
1st Level \\
Down
\end{tabular} & $\begin{array}{c}\text { 2nd Level } \\
\text { Down }\end{array}$ & $\begin{array}{l}\text { 3rd Level } \\
\text { Down }\end{array}$ & $\begin{array}{c}\text { 4th Level } \\
\text { Down }\end{array}$ & \begin{tabular}{c|c|c|} 
1st \\
Level
\end{tabular} & $\begin{array}{l}\text { 2nd } \\
\text { Level }\end{array}$ & $\begin{array}{l}\text { 3rd } \\
\text { Level }\end{array}$ \\
\hline \multicolumn{10}{|c|}{$\begin{array}{l}\text { Type (Faculty Type where IS resides) = B=Business, } T=\text { Technology, } \mathrm{O}=\mathrm{Other} \text { (e.g. Arts), 2=Both (Has IS groups in both B and T), C=Combined (Has B \& T } \\
\text { in a single faculty) } \ldots \text { Era = SS=Sandstone, RB=Redbrick, GT=Gumtrees, UT=Unitech, NU=New University, PU=Private University }\end{array}$} \\
\hline \multicolumn{10}{|c|}{ West Australia (WA) } \\
\hline UT & B & $\begin{array}{l}\text { Curtin University of } \\
\text { Tech. }\end{array}$ & $\begin{array}{l}\text { Curtin Business } \\
\text { School }\end{array}$ & $\begin{array}{l}\text { School of } \\
\text { Information } \\
\text { Systems }\end{array}$ & & & Division & School & \\
\hline $\mathrm{NU}$ & B & $\begin{array}{l}\text { Edith Cowan } \\
\text { University }\end{array}$ & $\begin{array}{c}\text { Faculty of Business } \\
\text { and Law }\end{array}$ & $\begin{array}{l}\text { School of } \\
\text { Information } \\
\text { Systems }\end{array}$ & & & Faculty & School & \\
\hline GT & $\mathrm{O}$ & Murdoch University & Division of Arts & $\begin{array}{c}\text { School of } \\
\text { Information Tech. }\end{array}$ & (IS group) & & Division & School & \\
\hline $\mathrm{PU}$ & B & $\begin{array}{c}\text { University of Notre } \\
\text { Dame }\end{array}$ & College of Business & School of Business & (IS) & & College & School & \\
\hline SS & B & $\begin{array}{c}\text { University of } \\
\text { Western Australia }\end{array}$ & $\begin{array}{c}\text { Faculty of } \\
\text { Economics and } \\
\text { Commerce }\end{array}$ & Business School & $\begin{array}{c}\text { Information } \\
\text { Mgmt } \\
\text { Discipline }\end{array}$ & (IS group) & Faculty & School & Discipline \\
\hline
\end{tabular}

\section{LOCATION OF IS IN UNIVERSITIES IN AUSTRALIA - A META-ANALYSIS}

Table 13 summarizes the placement of IS at Australian universities. "Business" includes faculties which are called business, economics or commerce. "Technology" includes faculties that called science, IT, or engineering. "Both" refers to universities that have an information systems group in both the "business" and the "technology" faculty types. "Combined" is where the university has a combined faculty called something like business and technology. "Other" indicates that IS is situated in some other type of faculty such as arts. Several universities reported that they were in the process of restructuring.

From Table 13 we note that IS is located within business at 17 universities, in technology at 11 , and in other at 2. At 5 universities, IS exists in both business and technology, and in four universities IS resides in a combined business-technology area. IS is located solely in business in 44 percent of universities (17), solely in technical in 28 percent of universities (11), in business or business and technical $(17+5)$ in 56 percent of universities, in technical or technical and business $(11+5)$ in 41 percent of universities. Broadly we observe an approximately 60/40 ratio of business versus technical.

We further note that IS is relatively more often located within business for all but 1 of the 6 "Eras," with IS more often located in technical only at the Unitech universities. Information Systems at the "Sandstones" is generally associated with the faculty of commerce/business/economics. In two of the three "Redbrick" universities (Australian National University and University of New South Wales), the main concentration of Information Systems seems to be in the faculty of 
economics/commerce. The other "Redbrick," Monash, has a faculty of Information Technology where IS is sited. Though the Australian Defence Force Academy is a college of the University of New South Wales, IS there is located within a school of technology. Three of the five "Unitechs" (Queensland University of Technology, University of Technology Sydney, University of South Australia) have faculties/divisions of Information Technology where Information Systems is concentrated. At the other two "Unitechs" (Curtin and RMIT) Information Systems is associated with business.

Table 13. IS in Business or Technology

\begin{tabular}{|r|c|c|c|c|c|c|}
\hline Era & Business & Tech & Both & Combined & Other & Total \\
\hline Gum Tree & 4 & 3 & 2 & & 1 & 10 \\
Unitech & 2 & 3 & & & & 5 \\
Sandstone & 3 & 1 & 2 & & & 6 \\
Red Brick & 2 & 1 & & & & 3 \\
New & 5 & 3 & 1 & 3 & 1 & 13 \\
Private & 1 & & & 1 & & 2 \\
\hline \hline Count: & 17 & 11 & 5 & 4 & 2 & 39 \\
\hline \hline
\end{tabular}

NB: Several universities have more than one IS group in the same faculty type e.g. Deakin has IS groups in the School of Information Systems and the Deakin Business School both of which are within the Faculty of Business and Law. ADFA was not included in the count.

There is little pattern to the placement of IS at the "Gumtrees" universities; four have Information Systems situated in business type faculties, three in technology faculties and two (Macquarie and Griffith) have IS groups in both types of faculty. Information Systems groups are most often associated with business at the "New" universities; however, there seems to be a trend towards the creation a faculty that combines business and informatics/computing at some of these universities. Three of the "new" universities have this type of combined faculty.

Table 14 indicates the frequency of generic terms for Administrative Organizational Units (AOUs) across universities in Australia. The prevailing confusion is immediately apparent, with the term "faculty" being used at both levels 1 and 2; "school" at levels 1, 2 and 3; and "department" at levels 2 and 3. At several universities a given level has different names within the same institution. At the University of Melbourne for example the second level may be called either a school or a department. Within some universities the business school is equivalent to, and has the status of a faculty, which sometimes results in different naming conventions being used for the levels within business (e.g. Griffith). The most commonly used terms for levels 1, 2 and 3 are faculty, school and discipline respectively.

The number of IS groups that are 1, 2, 3 or 4 levels down in their university's administrative structure are 0,13, 20 and 6 respectively. Only the main IS group at each university was included in this count. ${ }^{15}$ The Australian Defence Force Academy has a unique structure and was not included in the count. ${ }^{16}$

${ }^{15}$ Thus even though IS resides in several parts of several universities, counts in this table sum to the 39 Australian universities

16 Though much effort has been expended seeking to insure these data are accurate, undoubtedly there may be inaccuracies for which we apologize. 
Table 14. Most to Least Frequently Used Terms for AOUs

\begin{tabular}{|c|c|c|c|c|c|c|c|}
\hline \multicolumn{8}{|c|}{ Levels Down } \\
\hline \multicolumn{2}{|c|}{$1 \mathrm{st}$} & \multicolumn{2}{|l|}{2 nd } & \multicolumn{2}{|l|}{$3 r d$} & \multicolumn{2}{|c|}{ 4th } \\
\hline Term & $\#$ & Term & $\#$ & Term & \# & Term & $\#$ \\
\hline Faculty & 29 & School & 32 & Discipline & 7 & $\mathrm{n} / \mathrm{a}$ & 39 \\
\hline Division & 4 & School or Dept & 2 & Dept & 3 & & \\
\hline College & 4 & Faculty & 1 & Program & 1 & & \\
\hline Group & 1 & Division & 1 & School or Dept & 1 & & \\
\hline \multirow[t]{4}{*}{ School } & 1 & Dept & 1 & $\mathrm{n} / \mathrm{a}$ & 27 & & \\
\hline & & Academic Group & 1 & & & & \\
\hline & & $\mathrm{n} / \mathrm{a}$ & 1 & & & & \\
\hline & 39 & & 39 & & 39 & & 39 \\
\hline \multicolumn{3}{|c|}{ \# IS at this level } & 13 & & 20 & & 6 \\
\hline
\end{tabular}

Little can be inferred from this data on the level of placement of IS groups. Though on average, one would expect some correlation between levels down, and size and independence or autonomy of the IS group, deeper scrutiny reveals that each case is unique (e.g. see the state case reports). What we can say is that in over 33 percent of cases the IS group is only two levels down, in a further 51 percent of cases IS is three levels down, and in 15 percent of cases IS is four levels down. The most consistent pattern of IS placement is at the Unitechs, with four of the five Unitechs having an IS AOU at the second level.

\section{CONCLUSION}

While IS has a substantive presence in a most Australian universities, in some it is yet perceived as "a mere service discipline" [Clarke 2006, p.134]. Although in general, IS researchers felt that their research was not highly contingent upon local exigencies and environmental pressures, the topics researched often reflected personal interests and were only weakly coordinated across research sites. At this time IS in Australia does not possess a unique symbol system that allows unambiguous communication between initiates within the field.

To conclude this Australian case study, the following section describes: (1) further planned or in progress research, and (2) study limitations.

\section{FURTHER RESEARCH}

As represented in Figure 2 by unshaded ovals, there are two further studies yet to be completed as part of the study of the Information Systems academic discipline in Australia.

\section{The ACIS Archival Analysis}

As discussed earlier in this report, the required archival data, comprising data on each paper from the 16 years of the Australasian Conference in Information Systems (AJIS), has been captured in suitable electronic forms to permit ready analysis. This analysis is progressing and more comprehensive results are expected to be available in 2007, though outside the timeframe of the CAIS special issue. 


\section{The IS Research Issues Survey}

In March 2005, a global survey of issues facing IS researchers yielded 800 responses. It is intended that the Australian responses be extracted from the data for analysis. It is expected that analysis of this data will throw light on a further aspect of the IS academic discipline in Australia viz. the issues important to contemporary IS academic researchers.

\section{LIMITATIONS}

As acknowledged at various points in this paper, the study was a learning experience, a major aim being to evolve an approach that could be repeated across time and across regions; as such, its limitations are many, several of which have been specified throughout this paper.

\section{ACKNOWLEDGEMENTS}

This study of the Information Systems Academic Discipline in Australia has made significant demands on Queensland University of Technology (QUT), in terms of the time of Senior Research Associates Bob Smyth and Karen Stark, the provision of the study team Web site, facilities for conferencing, and numerous other resources to support the project. I wish to acknowledge here my appreciation to QUT for this significant provision of resources to make the study achievable.

\section{REFERENCES}

Editor's Note: The following reference list contains hyperlinks to World Wide Web pages. Readers who have the ability to access the Web directly from their word processor or are reading the paper on the Web, can gain direct access to these linked references. Readers are warned, however, that:

1. These links existed as of the date of publication but are not guaranteed to be working thereafter.

2. The contents of Web pages may change over time. Where version information is provided in the References, different versions may not contain the information or the conclusions referenced.

3. The author(s) of the Web pages, not AIS, is (are) responsible for the accuracy of their content.

4. The author(s) of this article, not AIS, is (are) responsible for the accuracy of the URL and version information.

Barki, H., S. Rivard, and J. Talbot. (1993). "A Keyword Classification Scheme for IS Research Literature: an Update," MIS Quarterly, (17)2, pp. 209-226.

Clarke, R. (2006). "Key Aspects of the History of the Information Systems Discipline in Australia," Australasian Journal of Information Systems, (14)1, pp.123-140.

Gable, G. (2006) "The Information Systems Discipline in Australian Universities: A Contextual Framework", Australasian Journal of Information Systems, (14)1, pp. 103-122.

Gable, G. G. (2002). State of the Information Systems Academic Discipline in the Pacific Asia Region. Proposal to Association for Information Systems (AIS) submitted to AIS Council at ICIS 2002 in Barcelona. [Data file]. Available from http://sky.fit.qut.edu.au/ gable/

Gregor, S., E. Lewis, and C. McDonald. (2006). "Case Study: The State of Information Systems in Australian Capital Territory Universities," Australasian Journal of Information Systems, (14)1, pp. 177-192. 
Koronios, A. and Swatman, Paula. (2006). "The State of Information Systems in Australian Universities - South Australia Report," Australasian Journal of Information Systems, (14)1, pp. 201-210.

Marginson, S. and M. Considine. (2000). The Enterprise University: Power, Governance, and Reinvention in Australia, Cambridge, UK: Cambridge University Press.

Maynard, G. B. (1992). "Report of the Task Force on the ACS towards 2000," Australian Computer Society.

Metcalfe, M. (2006). "Using Contradictions to Appreciate the History of I.S. Education in South Australia," Australasian Journal of Information Systems, (14)1, pp. 261-272.

Palvia, P. et al. (2004). "Research Methodologies in MIS: an Update," Communications of the AIS, (14), pp. 526-542.

Pervan G. and G. Shanks. (2004). "IS Research Activity in Australia: Results of the 2004 ACPHIS Research Survey," Presentation to Australasian Conference on Information Systems, December 2004.

Pervan, G.. and G. Shanks. (2006). "The 2005 Survey of Information Systems Research in Australia," Australasian Journal of Information Systems, (14)1, pp. 273-280.

Pollard, C. and E. S. K. Chan. (2006). "A Review of Information Systems Programs in Universities in Victoria," Australasian Journal of Information Systems, (14)1, pp. 231-250.

Ridley, G. (2006a). "Characterising Information Systems in Australia: A Theoretical Framework," Australasian Journal of Information Systems, (14)1, pp. 141-162.

Ridley, G. (2006b). "The State of Information Systems in Australian Universities - Tasmania Report," Australasian Journal of Information Systems, (14)1, pp.211-230.

Standing, C., J. Burn and C. Lin. (2006). "Information Systems in Western Australian Universities," Australasian Journal of Information Systems, (14)1, pp. 251-260.

Smyth, R. and G. Gable. (2006). "Case Study: The State of Information Systems in Queensland Universities," Australasian Journal of Information Systems, (14)1, pp. 163-176.

Underwood, J. and E. Jordan. (2006). "The State of IS in Australian Universities - New South Wales Report," Australasian Journal of Information Systems, (14)1, pp. 193-200.

Walsham, G. (1995). "Interpretive Case Studies in IS Research: Nature and Method," European Journal of Information Systems, (4), pp. 74-81.

Whitley, R. (1984a). "The Development of Management Studies as a Fragmented Adhocracy," Social Science Information, (23)4/5, pp. 775-818.

Whitley, R. (1984b). The Intellectual and Social Organization of the Sciences, Oxford, UK: Clarendon Press.

Yin, R. K. (2003). Case Study Research: Design and Methods, $3^{\text {rd }}$ edition, Thousand Oaks, CA.: Sage Publications.

\section{BIBLIOGRAPHY}

The other IS in Pacific Asia Region Study reports available in this volume of CAIS

Chau, P. Y. K. and K. K. Y. Kuan. (2007). "The Information Systems Academic Discipline in Hong Kong," Communications of the Association for Information Systems. 
Gable, G. (2007a). "The Information Systems Academic Discipline in Pacific Asia - a Contextual Analysis," Communications of the Association for Information Systems.

Gable, G., K-Y. Kwahk, J-N. Lee, and P. Green. (2007). "Administrative Placement of the Information Systems Academic Discipline: A Comparative SWOT Analysis," Communications of the Association for Information Systems.

Gable, G. and R. W. Smyth. (2007). "The Information Systems Academic Discipline in Pacific Asia - Methodological Learnings," Communications of the Association for Information Systems.

Lee, C-C and T-P. Liang. (2007). "The Information Systems Academic Discipline in Taiwan: A Focus on Top-Tier Universities," Communications of the Association for Information Systems.

Lee, J-N. and S-W. Yoo. (2007). "The Information Systems Academic Discipline in Korea: A Focus on Top-Tier Universities," Communications of the Association for Information Systems.

Lehmann, H. and S. Huff. (2007). "The Information Systems Academic Discipline in New Zealand" Communications of the Association for Information Systems.

Tan, B. and T. Chan. (2007). "The Information Systems Academic Discipline in Singapore," Communications of the Association for Information Systems.

\section{ABOUT THE AUTHOR}

Guy G. Gable is Professor of Information Systems and Chair of the IT Professional Services Research Program of the Faculty of Information Technology, Queensland University of Technology http://sky.fit.qut.edu.au/ gable/. His PhD is from University of Bradford and MBA from Ivey Business School. He is senior editor for the Journal of Strategic Information Systems, associate editor for MISQ, and on the editorial boards of Journal of the AIS, Information Systems Frontiers, and Australasian Journal of Information Systems. Key research interests include IT Professional Services, IT Research Methods, Enterprise Systems, and IT Evaluation. Career emphasis is on research collaboration with industry and the professions. He is Chief Investigator $(\$ 3.0 \mathrm{M}+)$ on grants with Accenture, SAP, Institute of Management

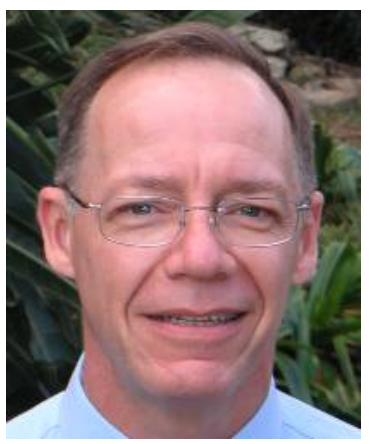
Consultants, and Queensland Treasury. He has published more than 100 referred journal articles, conference papers and books.

Copyright (C) 2007 by the Association for Information Systems. Permission to make digital or hard copies of all or part of this work for personal or classroom use is granted without fee provided that copies are not made or distributed for profit or commercial advantage and that copies bear this notice and full citation on the first page. Copyright for components of this work owned by others than the Association for Information Systems must be honored. Abstracting with credit is permitted. To copy otherwise, to republish, to post on servers, or to redistribute to lists requires prior specific permission and/or fee. Request permission to publish from: AIS Administrative Office, P.O. Box 2712 Atlanta, GA, 30301-2712 Attn: Reprints or via email from ais@aisnet.org 


\section{EDITOR-IN-CHIEF}

Joey F. George

Florida State University

AIS SENIOR EDITORIAL BOARD

\begin{tabular}{|l|l|l|}
\hline Guy Fitzgerald & Joey F. George & Kalle Lyytinen \\
Vice President Publications & Editor, CAIS & Editor, JAIS \\
Brunel University & Florida State University & Case Western Reserve University \\
\hline Edward A. Stohr & Blake Ives & Paul Gray \\
Editor-at-Large & Editor, Electronic Publications & Founding Editor, CAIS \\
Stevens Inst. of Technology & University of Houston & Claremont Graduate University \\
\hline
\end{tabular}

\section{CAIS ADVISORY BOARD}

\begin{tabular}{|l|l|l|l|}
\hline $\begin{array}{l}\text { Gordon Davis } \\
\text { University of Minnesota }\end{array}$ & $\begin{array}{l}\text { Ken Kraemer } \\
\text { Univ. of Calif. at Irvine }\end{array}$ & $\begin{array}{l}\text { M. Lynne Markus } \\
\text { Bentley College }\end{array}$ & $\begin{array}{l}\text { Richard Mason } \\
\text { Southern Methodist Univ. }\end{array}$ \\
\hline $\begin{array}{l}\text { Jay Nunamaker } \\
\text { University of Arizona }\end{array}$ & $\begin{array}{l}\text { Henk Sol } \\
\text { Delft University }\end{array}$ & $\begin{array}{l}\text { Ralph Sprague } \\
\text { University of Hawaii }\end{array}$ & $\begin{array}{l}\text { Hugh J. Watson } \\
\text { University of Georgia }\end{array}$ \\
\hline
\end{tabular}
\begin{tabular}{|l|l|l|l|}
\hline $\begin{array}{l}\text { Steve Alter } \\
\text { U. of San Francisco }\end{array}$ & $\begin{array}{l}\text { Jane Fedorowicz Holland } \\
\text { Manchester Bus. School }\end{array}$ & $\begin{array}{l}\text { Jerry Luftman } \\
\text { Stevens Inst. of Tech. }\end{array}$ \\
\hline
\end{tabular}

\section{CAIS EDITORIAL BOARD}

\begin{tabular}{|l|l|l|l|}
\hline $\begin{array}{l}\text { Michel Avital } \\
\text { Univ of Amsterdam }\end{array}$ & $\begin{array}{l}\text { Erran Carmel } \\
\text { American University }\end{array}$ & $\begin{array}{l}\text { Fred Davis } \\
\text { Uof Arkansas, Fayetteville }\end{array}$ & $\begin{array}{l}\text { Gurpreet Dhillon } \\
\text { Virginia Commonwealth U }\end{array}$ \\
\hline $\begin{array}{l}\text { Evan Duggan } \\
\text { Univ of the West Indies }\end{array}$ & $\begin{array}{l}\text { Ali Farhoomand } \\
\text { University of Hong Kong }\end{array}$ & $\begin{array}{l}\text { Robert L. Glass } \\
\text { Computing Trends }\end{array}$ & $\begin{array}{l}\text { Sy Goodman } \\
\text { Ga. Inst. of Technology }\end{array}$ \\
\hline $\begin{array}{l}\text { Ake Gronlund } \\
\text { University of Umea }\end{array}$ & $\begin{array}{l}\text { Ruth Guthrie } \\
\text { California State Univ. }\end{array}$ & $\begin{array}{l}\text { Alan Hevner } \\
\text { Univ. of South Florida }\end{array}$ & $\begin{array}{l}\text { Juhani livari } \\
\text { Univ. of Oulu }\end{array}$ \\
\hline $\begin{array}{l}\text { K.D. Joshi } \\
\text { Washington St Univ. }\end{array}$ & Michel Kalika & Jae-Nam Lee & Claudia Loebbecke \\
University of Cologne
\end{tabular}

\section{DEPARTMENTS}

Global Diffusion of the Internet.

Editors: Peter Wolcott and Sy Goodman Information Technology and Systems

Papers in French

Editor: Michel Kalika Editors: Alan Hevner and Sal March

ADMINISTRATIVE PERSONNEL

\begin{tabular}{|l|l|l|}
\hline $\begin{array}{l}\text { Eph McLean } \\
\text { AIS, Executive Director } \\
\text { Georgia State University }\end{array}$ & $\begin{array}{l}\text { Chris Furner } \\
\text { CAIS Managing Editor } \\
\text { Florida State Univ. }\end{array}$ & $\begin{array}{l}\text { Copyediting by Carlisle } \\
\text { Publishing Services }\end{array}$ \\
\hline
\end{tabular}

